Article

\title{
Preparation and Properties of a Sulphoaluminate Magnesium-Potassium Phosphate Green Cementitious Composite Material from Industrial Solid Wastes
}

\author{
Changzai Ren ${ }^{1, *}$, Wenlong Wang ${ }^{2}$, Dongliang Hua ${ }^{1}$, Shuang $\mathrm{Wu}^{2}$ and Yonggang Yao ${ }^{2}$ \\ 1 School of Energy and Power Engineering, Qilu University of Technology, Jinan 250306, China; \\ huadl@qlu.edu.cn \\ 2 National Engineering Laboratory for Coal-Fired Pollutants Emission Reduction, Shandong University, \\ Jinan 250061, China; wwenlong@sdu.edu.cn (W.W.); wushuanglc@163.com (S.W.); \\ youxiatianxia2008@163.com (Y.Y.) \\ * Correspondence: rcz@qlu.edu.cn
}

Citation: Ren, C.; Wang, W.; Hua, D.; $\mathrm{Wu}, \mathrm{S}$.; Yao, Y. Preparation and Properties of a Sulphoaluminate Magnesium-Potassium Phosphate Green Cementitious Composite Material from Industrial Solid Wastes. Materials 2021, 14, 7340. https:// doi.org/10.3390/ma14237340

Academic Editor: Jorge S. Dolado

Received: 13 September 2021

Accepted: 12 November 2021

Published: 30 November 2021

Publisher's Note: MDPI stays neutral with regard to jurisdictional claims in published maps and institutional affiliations.

Copyright: () 2021 by the authors. Licensee MDPI, Basel, Switzerland. This article is an open access article distributed under the terms and conditions of the Creative Commons Attribution (CC BY) license (https:// creativecommons.org/licenses/by/ $4.0 /)$.

\begin{abstract}
The preparation of high-performance green cementitious material from industrial solid waste is a feasible large-scale utilization approach for industrial solid waste. This work investigates the feasibility of using industrial solid wastes in a sulphoaluminate-magnesium-potassiumphosphate cementitious composite material (SAC-MKPC) clinker preparation and the influence of the calcination temperature and clinker ingredients on the hydration behavior and mechanisms of the SAC-MKPC with a Mg/P ratio of 5. The results show that the novel SAC-MKPC that was prepared from aluminum slag, carbide slag, coal gangue, and magnesium desulfurization slag was composed mainly of mineral $\mathrm{MgO}, \mathrm{C}_{4} \mathrm{~A}_{3} \overline{\mathrm{S}}$, and $\mathrm{C}_{2} \mathrm{~S}$ and the calcination temperature of the main mineral phases was $1250-1350{ }^{\circ} \mathrm{C}$. The solid-waste-based SAC-MKPC had better mechanical properties and excellent water resistance compared with the MKPC. The optimal compressive strength reached 35.2, 70.9, $84.1,87.7$, and $101.6 \mathrm{MPa}$ at $2 \mathrm{~h}, 1 \mathrm{~d}, 3 \mathrm{~d}, 7 \mathrm{~d}$, and $28 \mathrm{~d}$ of hydration, respectively. The X-ray diffraction spectra and scanning electron micrographs of the hydration products of the SAC-MKPC clinker showed that AFt and K-struvite crystals coexisted and adhered to form a dense structure. This work provides an innovative idea to produce green cementitious material using industrial solid wastes and may promote the sustainable development of the power and mining industries.
\end{abstract}

Keywords: industrial solid waste; sulphoaluminate-magnesium-potassium-phosphate cementitious composite material; clinker phase; water resistance; sustainable development

\section{Introduction}

The electrolytic aluminum, power, and mining industries produce large volumes of solid waste [1]. The industrial solid waste is dumped in huge volumes over a wide geographical distribution, which causes far-reaching environmental harm in China [2]. The preparation of eco-friendly construction materials from industrial solid waste is a feasible large-scale utilization method using current technologies [3]. Magnesium-potassium phosphate cement (MKPC) is an excellent air-hardening cementitious material with a wide range of applications, including urgent construction and repair, nuclear waste encapsulation, and three-dimensional printing building materials; however, the high energy consumption and poor water resistance of MKPC have constrained its application in engineering [4-6]. To improve MKPC's water stability and low carbon emission capability, extensive theoretical and experimental research has been conducted in three main areas, namely filling theory, interaction theory, and coating theory. In filling experiments and theoretical research, fly ash, nickel slag, and silica fume have been used as filling materials owing to their beneficial effects on improving the fresh mixture's workability and reducing the development of heat in MKPC-based blends, which led to a more compact microstructure of hardened 
MKPC paste [7-9]. In interaction experiments and theories, granulated blast furnace slag and metakaolin have been used as reactive materials in MKPC-based blends [10]. The two materials blend with MKPC to form a new amorphous phase, comprised of aluminum phosphate and calcium phosphate, which prevents water erosion [11]. In coating experiments and theories, amorphous calcium sulfoaluminate has been used as a coating material. Hydration products that were coated on the MKPC surface prevent water from entering the MKPC paste and improve the water resistance. A novel approach to improve the water resistance, reduce the use of natural resources, and maintain or improve the performance of MKPC is required.

The novel sulphoaluminate magnesium-potassium phosphate cementitious composite material (SAC-MKPC) was first proposed in 2017, and it exhibits excellent mechanical stability and favorable water stability $[12,13]$. The current findings suggest that unreacted SAC clinker particles and the hydration product have three functions (a filling effect, an interaction effect, and a coating effect) and improve the water resistance and performance. The novel SAC-MKPC exhibited better mechanical properties and excellent water resistance, in which the MKPC was composed of dead-burnt magnesia and potassium dihydrogen phosphate $\left(\mathrm{KH}_{2} \mathrm{PO}_{4}, \mathrm{KDP}\right)$. However, dead-burnt magnesia needs to be calcined at $1700{ }^{\circ} \mathrm{C}$ for 7-10 h, which requires more energy [14], and the high energy consumption was found to be the greatest disadvantage of the SAC-MKPC. We investigated the possibility of producing SAC-MKPC clinker from magnesium sulphate, calcium oxide, and aluminium oxide in different proportions, at low calcination temperatures, and using chemical reagents as raw materials [15].

To decrease the environmental pollution caused by industrial solid waste and to improve the added value of solid-waste-based products, a method of preparing SACMKPC clinker with typical industrial solid waste was proposed. Based on an analysis of a SAC and MKPC cement system, this study explores the possibility of producing SACMKPC clinker from a mixture of aluminum slag, carbide slag, coal gangue, and magnesium desulfurization slag at a low calcination temperature. The objective of this study is to determine the SAC-MKPC clinker's formation mechanism, hydration behavior, mechanical properties, and hydration products, the water resistance of the hydration products, and the microstructure of SAC-MKPC composites by X-ray diffraction (XRD), thermal gravitydifferential thermal gravity (TG-DTG) analysis, and scanning electron microscopy-energy dispersive spectrometry (SEM-EDS).

\section{Materials and Methods}

2.1. Experimental Instruments and Testing Methods

\subsubsection{Experimental Instruments}

The experiment was divided into three categories: raw material preparation, SACMAPC clinker preparation, and performance testing. The main pieces of experimental equipment were divided into raw material preparation equipment, clinker calcination and molding equipment, and analytical equipment. The main experimental equipment were shown as Table 1.

During the raw material's preparation, an electronic balance, a disc refiner, a sample pulverizer, a hot air oven, and a box resistance furnace were used to dry, weigh, grind, and homogenize the raw materials. During the clinker calcination and molding process, a standard sieve, a steel mold, and a cement paste vibration table were used to grind and mold the standard test blocks. In terms of the analytical performance of the clinker and hydration products, an automatic pressure measurement testing machine, $\mathrm{XRF}$, and $\mathrm{XRD}$ were used to study the mechanical properties, mineralogical compositions, and microstructure of the hydrated products, respectively. Thermal gravimetric analysis was used to determine the category and degree of the SAC-MKPC specimen's hydration products. 
Table 1. Main pieces of experimental equipment.

\begin{tabular}{|c|c|c|c|}
\hline Process & Experimental Instruments & Manufacturer/Model & Country \\
\hline \multirow{5}{*}{$\begin{array}{c}\text { Raw Material Preparation } \\
\text { Equipment }\end{array}$} & Electronic balance & $\begin{array}{l}\text { Shanghai Yueping Scientific Instrument } \\
\text { Co., Ltd.; FA2004B }\end{array}$ & China \\
\hline & Disc refiner & $\begin{array}{c}\text { Nanjing University Instrument Plant; } \\
\text { QM-3SP04 }\end{array}$ & China \\
\hline & Sample pulverizer & $\begin{array}{l}\text { Shanghai Shuli Yiqi Yibiao Co., Ltd.; } \\
\text { GJ100-1A }\end{array}$ & China \\
\hline & Hot air oven & $\begin{array}{l}\text { Shandong Luda Experiment Instrument } \\
\text { Co., Ltd.; DHG-9053 }\end{array}$ & China \\
\hline & Standard sieve & $\begin{array}{l}\text { Shandong Luda Experiment Instrument } \\
\text { Co., Ltd.; } 200 \text { mesh }\end{array}$ & China \\
\hline \multirow{6}{*}{$\begin{array}{l}\text { Clinker Calcination } \\
\text { and Molding Equipment }\end{array}$} & Box resistance furnace & $\begin{array}{l}\text { Hennan Jianxi Experiment Instrument Co., } \\
\text { Ltd.; KSL-1600X }\end{array}$ & China \\
\hline & Steel mold & $\begin{array}{l}\text { Shandong Luda Experiment Instrument } \\
\text { Co., Ltd.; } 20 \mathrm{~mm} \times 20 \mathrm{~mm} \times 20 \mathrm{~mm}\end{array}$ & China \\
\hline & Cement shaker & $\begin{array}{l}\text { Shandong Luda Experiment Instrument } \\
\text { Co., Ltd.; } 60 \text { times/min }\end{array}$ & China \\
\hline & Standard curing box & $\begin{array}{l}\text { Shandong Luda Experiment Instrument } \\
\text { Co., Ltd.; YH40B }\end{array}$ & China \\
\hline & Cement mortar vibration table & $\begin{array}{l}\text { Shandong Luda Experiment Instrument } \\
\text { Co., Ltd.; } 170 \mathrm{~mm} \times 110 \mathrm{~mm} \times 300 \mathrm{~mm}\end{array}$ & China \\
\hline & $\begin{array}{c}\text { Automatic pressure } \\
\text { measurement testing machine }\end{array}$ & $\begin{array}{l}\text { Shandong Luda Experiment Instrument } \\
\text { Co., Ltd.; DYH-300 B }\end{array}$ & China \\
\hline \multirow[t]{5}{*}{ Analysis Equipment } & Automatic setting time tester & $\begin{array}{c}\text { Jian Yan Hua Ce (Hangzhou) Science \& } \\
\text { Technology Co., Ltd. }\end{array}$ & China \\
\hline & SEM-EDS & $\begin{array}{l}\text { Fei Electron Microscope Co., Ltd.; } \\
\text { Quanta200; }\end{array}$ & Netherlands \\
\hline & X-ray diffraction & $\begin{array}{c}\text { Europe Italy Boris Pastemak Co., Ltd.; } \\
\text { Europe }\end{array}$ & Germany \\
\hline & X-ray fluorescence & $\begin{array}{c}\text { USA Thermal Scientific Co., Ltd.; } \\
\text { D8-Advance }\end{array}$ & America \\
\hline & TG-DTG & $\begin{array}{c}\text { NETZSCH STA } 409 \text { PC/PG Thermal } \\
\text { Analyzer }\end{array}$ & \\
\hline
\end{tabular}

\subsubsection{Testing Methods}

A. Initial setting time

At an ambient temperature of $25^{\circ} \mathrm{C}$, the setting time of the fresh SAC-MKPC paste was measured with the automatic setting time tester according to GB/T1346-2011 [16]. Since the time between the initial and the final setting was very short (several minutes), only the initial setting time is presented in this paper.

B. Specimen preparation and compressive strength

The SAC-MKPC paste was cast into 20-mm cubic molds, and molds with SAC-MKPC paste were cured in a curing box at a constant temperature and humidity of $25{ }^{\circ} \mathrm{C}$ and $55 \%$, respectively. After a curing time of $1 \mathrm{~h}$, the standard test block was demolded and cured in a standard curing box under the same conditions.

The compressive strength of the samples was measured using an automatic pressure measurement testing machine. Each proportion was measured as a set of two samples. The samples, after air curing for $2 \mathrm{~h}, 1$ day, 3 days, 7 days, and 28 days, were tested for compressive strength. To test the water resistance, the compressive strength of the samples was measured after 28 days in water. Before testing, the samples immersed in water were taken out of the water and dried for $4 \mathrm{~h}$.

C. Thermal gravity-differential thermal gravity (TG-DTG) analysis

In the thermal mass tests, the mass of the test paste powder was $\sim 20 \mathrm{mg}$, and the temperature range of the thermogravimetry test was $30-700{ }^{\circ} \mathrm{C}$ at $10^{\circ} \mathrm{C} / \mathrm{min}$. TG-DTG 
analyses were used to investigate the mineral composition phases of the SAC-MKPC hydrated product.

D. XRD analysis

The mineral composition phases of the SAC-MKPC clinker and hydration products were identified by XRD with a Ni filter and $\mathrm{Cu}-\mathrm{Ka}(\mathrm{k}=1.5406 \AA$ Á) radiation at $40 \mathrm{kV}$ and $30 \mathrm{~mA}$ and at a scanning speed of $0.02^{\circ} / \mathrm{s}$ over a $2 \mathrm{~h}$ range and $10-90^{\circ}$ with 4000 data points. A quantitative analysis of the main phase was conducted by using the "TOPAS" software package and the fitted parameters included the background coefficients, instrument parameters, sample corrections, cell parameters, and phase-shape parameters. The pseudo-Voigt function, structure, and Inorganic Crystal Structure Database (ICSD) codes used for the Rietveld refinement were based on our previous research [17].

E. Microstructure and morphology

Hydration samples were collected from the middle sections of the SAC-MKPC paste specimens and immersed in anhydrous alcohol for at least two days to stop further hydration. The samples were vacuum-dried at $60^{\circ} \mathrm{C}$ for $24 \mathrm{~h}$. The morphologies of the hydration products in the hardened MKPC paste were analyzed by using a QUANTA-200 environmental scanning electron microscope and chemical characterization was performed using EDS. The samples were coated with gold before examination to improve the conductivity.

\subsection{Materials}

Industrial solid wastes (aluminum slag, carbide slag, coal gangue, and magnesium desulfurization slag (MDS)) were used to prepare SAC-MKPC clinkers. Magnesium desulfurization slag was collected from Weiqiao coal-fired power plants. Aluminum slag was supplied by Weiqiao Pioneering, Shandong. Carbide slag was obtained from Liaocheng acetylene company, and coal gangue was obtained from Taifeng Group Ming in Taian, Shandong. The main oxide compositions of the initial raw materials were analyzed chemically by wavelength-dispersive $\mathrm{X}$-ray fluorescence $(\mathrm{XRF})$. Because of the release of gaseous ammonia from the $\mathrm{MgO}-\mathrm{NH}_{4} \mathrm{H}_{2} \mathrm{PO}_{4}$ system, $\mathrm{KH}_{2} \mathrm{PO}_{4}(\mathrm{KDP})$ was one of the main raw materials in the SAC-MKPC preparation. The chemical composition of the raw materials is presented in Table 2.

Table 2. Chemical composition of the raw materials (wt $\%)$.

\begin{tabular}{|c|c|c|c|c|c|c|c|c|c|c|}
\hline & $\mathrm{MgO}$ & $\mathrm{Al}_{2} \mathrm{O}_{3}$ & $\mathrm{SiO}_{2}$ & $\mathrm{SO}_{3}$ & $\mathrm{CaO}$ & $\mathrm{Fe}_{2} \mathrm{O}_{3}$ & $\mathrm{TiO}_{2}$ & $\mathrm{R}_{2} \mathrm{O}^{\mathrm{a}}$ & LOI $^{b}$ & SAM $^{c}$ \\
\hline Carbide Slag & 0.34 & 1.33 & 1.41 & 1.24 & 75.05 & 0.25 & 0.03 & 0.21 & 20.14 & \multirow{4}{*}{$\begin{array}{c}\mathrm{KH}_{2} \mathrm{PO}_{4} \\
\quad(99 \%, \\
\text { Aladdin) }\end{array}$} \\
\hline Aluminum Slag & 4.87 & 70.79 & 9.65 & 0.41 & 1.95 & 4.11 & 0.49 & 3.51 & 4.22 & \\
\hline Coal Gangue & 2.55 & 20.16 & 61.62 & 1.95 & 2.27 & 3.28 & 1.24 & 0.71 & 6.22 & \\
\hline MDS & 31.46 & 1.21 & 1.03 & 58.15 & 1.26 & 0.31 & 0.12 & 0.23 & 6.23 & \\
\hline
\end{tabular}

a Alkaline oxide $\left(\mathrm{K}_{2} \mathrm{O}, \mathrm{Na}_{2} \mathrm{O}\right) .{ }^{\mathrm{b}}$ Loss on ignition at $950{ }^{\circ} \mathrm{C}$. ${ }^{\mathrm{c}}$ Secondary added materials.

The magnesium desulfurization slag was formed by $\mathrm{SO}_{2}$ absorption by light-burned magnesium oxide in a desulfurization tower. The XRD pattern of the magnesium desulfurization slag is shown in Figure 1a. The magnesium desulfurization slag was mainly composed of magnesium sulfite hexahydrate $\left(\mathrm{MgSO}_{3} \cdot 6 \mathrm{H}_{2} \mathrm{O}\right)$, magnesium sulfate heptahydrate $\left(\mathrm{MgSO}_{4} \cdot 7 \mathrm{H}_{2} \mathrm{O}\right)$, calcium oxide $(\mathrm{CaO})$, and magnesium hydroxide $\left(\mathrm{Mg}(\mathrm{OH})_{2}\right)$. $\mathrm{MgSO}_{3} \cdot 6 \mathrm{H}_{2} \mathrm{O}, \mathrm{MgSO}_{4} \cdot 7 \mathrm{H}_{2} \mathrm{O}$, and $\mathrm{Mg}(\mathrm{OH})_{2}$ are the most important major phases in magnesium desulfurization slag, and these phases comprise $95 \%$ of the magnesium desulfurization slag material. Carbide slag is an industrial waste that is generated from the hydrolysis of calcium carbide $\left(\mathrm{CaC}_{2}\right)$ during acetylene production [18]. Figure $1 \mathrm{~b}$ presents the XRD pattern of carbide slag, where the main phases are calcium hydroxide $\left(\mathrm{Ca}(\mathrm{OH})_{2}\right)$, calcium carbonate $\left(\mathrm{CaCO}_{3}\right)$, and magnesium oxide $(\mathrm{MgO})$. Silicon dioxide $\left(\mathrm{SiO}_{2}\right)$ and ferric oxide $\left(\mathrm{Fe}_{2} \mathrm{O}_{3}\right)$ are the most important minor phases in carbide slag. $\mathrm{Ca}(\mathrm{OH})_{2}, \mathrm{CaCO}_{3}$, and $\mathrm{MgO}$ 
are the most important major phases in the carbide slag and comprise $92 \%$ of the carbide slag phase. Aluminum slag is generated by the secondary aluminum industry. Figure $1 \mathrm{c}$ presents the XRD patterns of aluminum slag. It contains aluminum and aluminum oxide, and may include many impurities, such as sodium chloride, potassium chloride, calcium fluoride, sodium fluoride, aluminum, aluminum nitride, magnesium chlorides, and some heavy metals [1]. The major mineral phase contents of $\mathrm{Al}_{1} \mathrm{Al}_{2} \mathrm{O}_{3}, \mathrm{AlN}$, and $\mathrm{SiO}_{2}$ comprise $\sim 90 \%$ of the main components. Coal gangue is the tailing that is produced by coal mining. Figure $1 \mathrm{~d}$ presents the XRD pattern of coal gangue. The main phases are silicon dioxide $\left(\mathrm{SiO}_{2}\right)$, aluminum oxide $\left(\mathrm{Al}_{2} \mathrm{O}_{3}\right)$, and magnesium oxide $(\mathrm{MgO})$. Some minor-phase $\mathrm{CaO}$, $\mathrm{TiO}_{2}$, and potassium salts are present and the main phases account for more than $80 \%$ of the content.

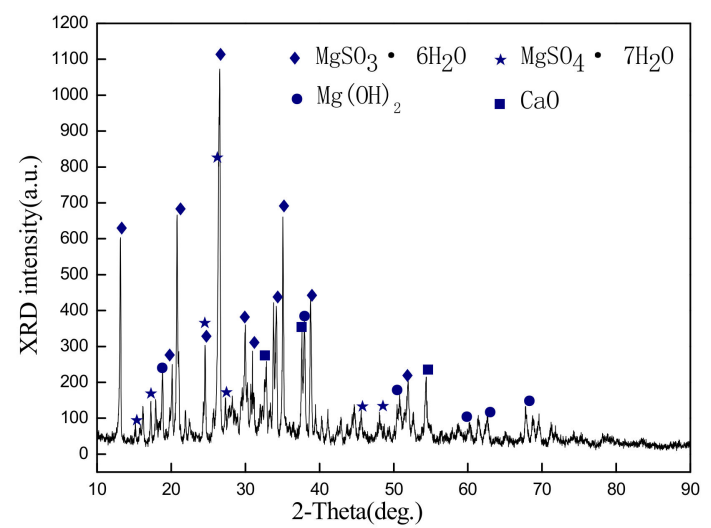

(a)

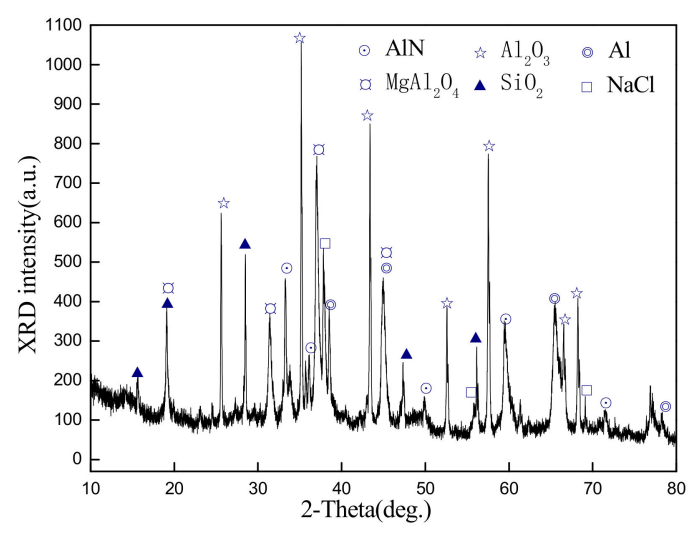

(c)

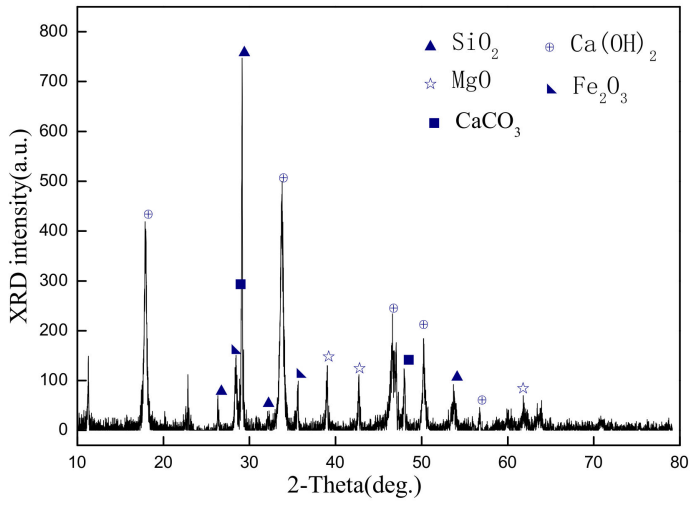

(b)

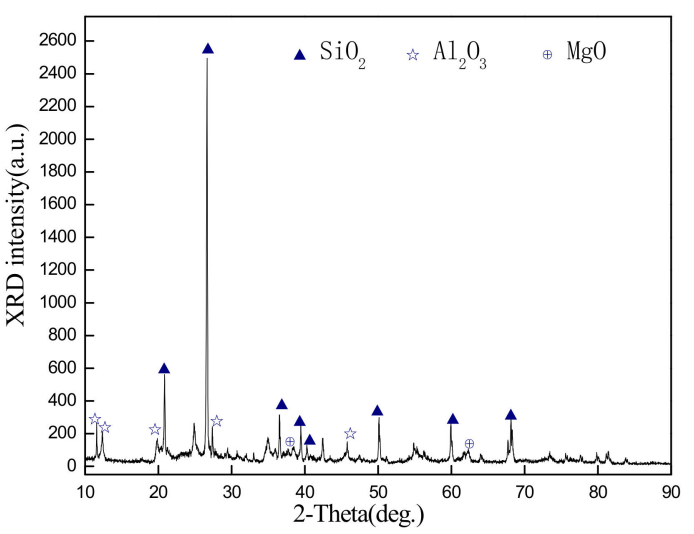

(d)

Figure 1. XRD patterns of raw materials: (a) magnesium desulfurization slag; (b) carbide slag; (c) aluminum slag; (d) coal gangue.

Figure 2a shows the TG-DTG outputs of the magnesium desulfurization slag. The MDS decomposition occurred in three main stages. $\mathrm{MgSO}_{3} \cdot 6 \mathrm{H}_{2} \mathrm{O}$ and $\mathrm{MgSO}_{4} \cdot 7 \mathrm{H}_{2} \mathrm{O}$ began to lose crystalline water from 150 to $230{ }^{\circ} \mathrm{C}$. When the temperature exceeded $230{ }^{\circ} \mathrm{C}$, $\mathrm{MgSO}_{3} \cdot 6 \mathrm{H}_{2} \mathrm{O}$ and $\mathrm{MgSO}_{4} \cdot 7 \mathrm{H}_{2} \mathrm{O}$ lost all of their crystalline water and transformed to anhydrous $\mathrm{MgSO}_{3}$ and $\mathrm{MgSO}_{4}$. When the temperature reached $430{ }^{\circ} \mathrm{C}$, the $\mathrm{MgSO}_{3}$ began to decompose and form $\mathrm{MgO}$ and $\mathrm{SO}_{2}$, and the decomposition was completed at $550{ }^{\circ} \mathrm{C}$, with a heat loss of $31 \%$. When the temperature exceeded $900{ }^{\circ} \mathrm{C}$, the $\mathrm{MgSO}_{4}$ began to decompose and transform into $\mathrm{MgO}, \mathrm{O}_{2}$, and $\mathrm{SO}_{2}$. When the temperature exceeded $1060^{\circ} \mathrm{C}$, the magnesium sulfate was decomposed completely, the thermal mass loss reached $65 \%$, the quality remained unchanged, and the thermal decomposition was complete. Figure $2 b$ shows the TG-DTG outputs of the carbide slag. Two tiny peaks appear on the DTG curve 
at $80^{\circ} \mathrm{C}$ and $115^{\circ} \mathrm{C}$ and are caused mainly by the loss of free and crystalline water of the carbide slag [19]. When the temperature reached $400{ }^{\circ} \mathrm{C}$, the $\mathrm{Ca}(\mathrm{OH})_{2}$ began to decompose and converted into $\mathrm{H}_{2} \mathrm{O}$ and $\mathrm{CaO}$, and the decomposition was completed at $500{ }^{\circ} \mathrm{C}$. As the temperature continued to increase, the $\mathrm{CaCO}_{3}$ began to decompose and generated $\mathrm{CaO}$ and released $\mathrm{CO}_{2}$ between 600 and $750{ }^{\circ} \mathrm{C}$. Hence, the main quality loss for the carbide slag was the decomposition of $\mathrm{Ca}(\mathrm{OH})_{2}$ and $\mathrm{CaCO}_{3}$.

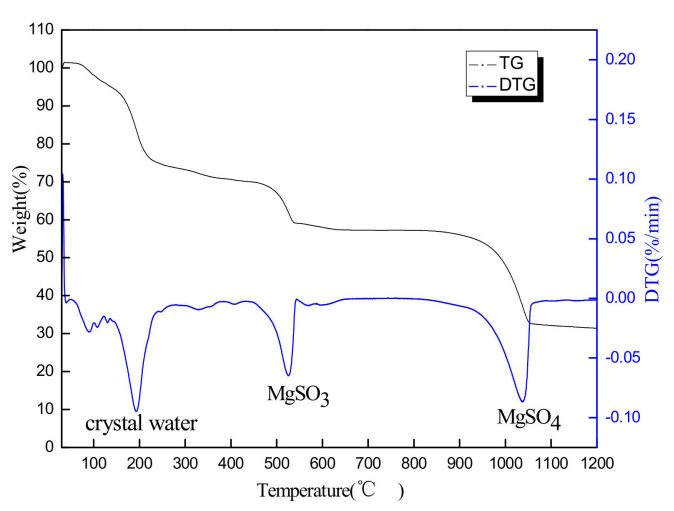

(a)

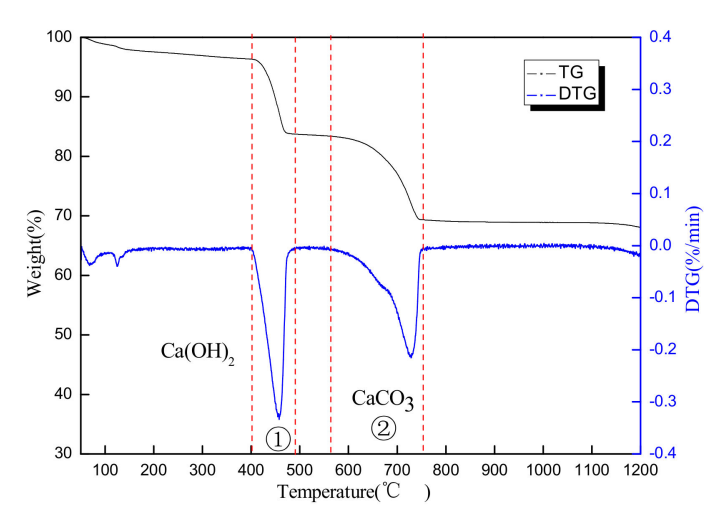

(b)

Figure 2. TG-DTG outputs of raw materials: (a) magnesium desulfurization slag; (b) carbide slag.

\subsection{Experimental Methods}

The SAC-MKPC cementitious composite material was prepared in the laboratory. The main experimental steps included raw mix preparation, calcining, secondary mixing, and molding.

\section{(1) Raw mix preparation}

Based on an analysis of the XRD patterns and TG-DTG outputs of the main raw materials and previous research (Section 2.1), the main possible chemical reactions of the solid-state materials were as follows.

(a) Calcium sulfate, magnesium oxide, and calcium oxide formed through the solid-state reactions of magnesium desulfurized slag and carbide slag [20].

$\mathrm{Ca}(\mathrm{OH})_{2}+\mathrm{CaCO}_{3}+\mathrm{MgSO}_{3}+\mathrm{MgSO}_{4} \rightarrow \mathrm{CaSO}_{4}+\mathrm{MgO}+\mathrm{CaO}+\mathrm{SO}_{2} \uparrow+\mathrm{O}_{2} \uparrow+\mathrm{CO}_{2} \uparrow+\mathrm{H}_{2} \mathrm{O}$

(b) Calcium oxide, aluminium oxide, and calcium sulfate transformed into the ye'elimite phase.

$$
3 \mathrm{CaO}+3 \mathrm{Al}_{2} \mathrm{O}_{3}+\mathrm{CaSO}_{4} \rightarrow 3 \mathrm{CaO} \cdot 3 \mathrm{Al}_{2} \mathrm{O}_{3} \cdot \mathrm{CaSO}_{4}
$$

(c) Magnesium oxide transformed into dead-burnt magnesium oxide [21].

$$
\mathrm{MgO} \rightarrow \text { dead-burnt } \mathrm{MgO}
$$

Based on the above chemical reaction mechanism, the main possible reaction products were dead-burnt $\mathrm{MgO}, \mathrm{CaSO}_{4}$, and $3 \mathrm{CaO} \cdot 3 \mathrm{Al}_{2} \mathrm{O}_{3} \cdot \mathrm{CaSO}_{4}\left(\mathrm{C}_{4} \mathrm{~A}_{3} \overline{\mathrm{S}}\right)$ in the SAC-MKPC clinker system. Six different raw material ratio schemes were designed. $\mathrm{MgO}$ had a theoretical $40 \%, 50 \%, 60 \%, 70 \%, 80 \%$, and $100 \%$ share of the SAC-MKPC clinker system, respectively. Table 3 shows the proportions of raw materials and the calcination conditions. 
Table 3. Compositions of raw mixes in the experiment with different calcination temperatures.

\begin{tabular}{|c|c|c|c|c|c|c|c|c|}
\hline Sample & $\begin{array}{c}\text { Coal } \\
\text { Gangue/g }\end{array}$ & $\begin{array}{l}\text { Aluminum } \\
\text { Slag/g }\end{array}$ & MDS/g & $\begin{array}{l}\text { Carbide } \\
\text { Slag/g }\end{array}$ & $\begin{array}{c}\text { Calcination } \\
\text { Temperature } /{ }^{\circ} \mathrm{C}\end{array}$ & $\begin{array}{l}\text { Holding } \\
\text { Time/Min }\end{array}$ & $\begin{array}{l}\text { Temperature } \\
\text { Interval } /{ }^{\circ} \mathrm{C}\end{array}$ & $\begin{array}{c}\text { MgO } \\
\text { Theoretical } \\
\text { Content } / \mathbf{w t} \%\end{array}$ \\
\hline A & 1.22 & 14.33 & 63.74 & 20.71 & $1200-1350$ & $30 \mathrm{~min}$ & 50 & $40 \%$ \\
\hline B & 0.75 & 8.63 & 76.73 & 13.89 & $1200-1350$ & $30 \mathrm{~min}$ & 50 & $50 \%$ \\
\hline $\mathrm{C}$ & 0.43 & 5.09 & 84.86 & 9.62 & $1200-1350$ & $30 \mathrm{~min}$ & 50 & $60 \%$ \\
\hline $\mathrm{D}$ & 0.23 & 2.71 & 90.43 & 6.63 & $1200-1350$ & $30 \mathrm{~min}$ & 50 & $70 \%$ \\
\hline $\mathrm{E}$ & 0.15 & 1.67 & 93.07 & 5.11 & $1200-1350$ & $30 \mathrm{~min}$ & 50 & $80 \%$ \\
\hline $\mathrm{F}$ & 0 & 0 & 100 & 0 & $1200-1350$ & $30 \mathrm{~min}$ & 50 & $100 \%$ \\
\hline
\end{tabular}

(2) According to the raw mixes in Table 2, a raw material block was prepared by mixing the raw materials and breaking, grinding, pressing, and drying the block. The dried raw material samples were calcined under electrical resistance, and the calcination temperature curve is shown in Figure 3. Mineral phases of the raw materials lost crystalline water below $400^{\circ} \mathrm{C}$, and, hence, the temperature increment was $8^{\circ} \mathrm{C} / \mathrm{min}$. The decomposition reaction of calcium hydroxide and magnesium sulfite hexahydrate occurred from 400 to $800{ }^{\circ} \mathrm{C}$ and the temperature increment was set at $5^{\circ} \mathrm{C} / \mathrm{min}$ to achieve a complete reaction. The decomposition reaction of calcium carbonate and magnesium sulfate occurred, and the transient phase of calcium sulfate and gehlenite formed, at $800-1100{ }^{\circ} \mathrm{C}$; hence, the rate of temperature increase was $4{ }^{\circ} \mathrm{C} / \mathrm{min}$. When the temperature exceeded $1100{ }^{\circ} \mathrm{C}$, the calcined temperature increased from room temperature to the set point temperature and $3 \mathrm{CaO} \cdot 3 \mathrm{Al}_{2} \mathrm{O}_{3} \cdot \mathrm{CaSO}_{4}$ and dead-burnt $\mathrm{MgO}$ formed. The temperature increment was $5{ }^{\circ} \mathrm{C} / \mathrm{min}$ and the final temperature was maintained for $30 \mathrm{~min}$. After calcination, the samples were taken out of the furnace and allowed to cool naturally to room temperature in air.

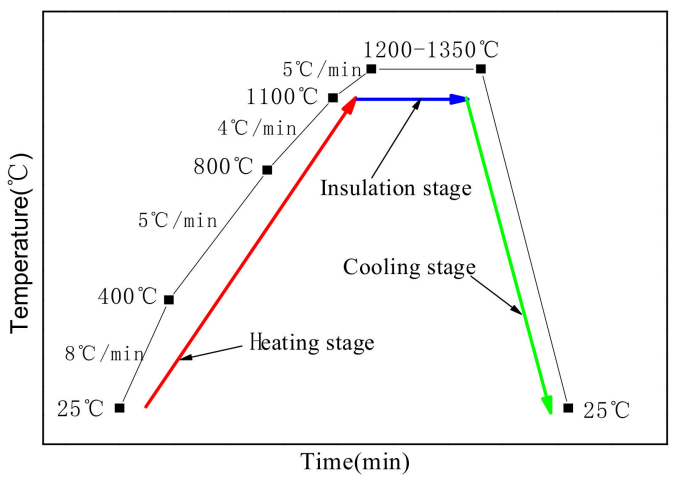

Figure 3. Calcination temperature increase control curve.

(3) Secondary mixing method

The hydration products of the SAC-MKPC cementitious composite material were comprised mostly of a magnesium-oxide particle skeleton, potassium phosphate, and ettringite. The main mineral phases included dead-burnt $\mathrm{MgO}, \mathrm{C}_{4} \mathrm{~A}_{3} \overline{\mathrm{S}}$, and calcium sulphate for the SAC-MKPC clinker system. Hence, the SAC-MKPC cementitious composite material required secondary mixing with SAC-MKPC clinker, gypsum, and salt phosphate. According to previous research [22-26], the performance of the SAC-MKPC cementitious composite material depends on the magnesia-to-phosphate molar ratio $(\mathrm{M} / \mathrm{P})$, the phosphate type, and the water-to-binder ratio. For the two single systems, MKPC was prepared with a water $/$ binder ratio $(w / b)$ of 0.16 , and SAC was prepared with a w/b of $0.28[12,27]$. Each addition of a SAC-MKPC clinker sample was to the same M/P. The M/P was set to 5/1, and gypsum of $5 \%$ mass SAC was added [28]. Therefore, for the SAC-MKPC system, the $\mathrm{w} / \mathrm{b}$ mass ratio was $16 \%$ of the binder (where the binder was the total of $\mathrm{MgO}$ and $\mathrm{KH}_{2} \mathrm{PO}_{4}$ ) and $28 \%$ of the SAC. Several different water requirements were used, including 29.4, 29.6, 29.7, 29.8, and 29.9 (g/100 g) when the theoretical MgO contents were $40 \mathrm{wt} . \%$, 
50 wt. $\%, 60$ wt. $\%, 70$ wt. $\%$, and 80 wt. $\%$, respectively. The SAC-MKPC clinker was prepared according to the experimental schemes shown in Table 2 and the calcination temperature increase control curve shown in Figure 3. Table 3 shows the chemical components of the different SAC-MKPC clinker samples as measured by XRF, and the additive amount of $\mathrm{KH}_{2} \mathrm{PO}_{4}$, gypsum, and water for all clinker samples was estimated according to the XRF data. The amounts of added $\mathrm{KH}_{2} \mathrm{PO}_{4}$, water, and gypsum are listed in Table 4.

Table 4. Mix proportions for the secondary mixing (g/100 g clinker).

\begin{tabular}{|c|c|c|c|c|c|c|c|c|c|c|}
\hline Sample & $\mathrm{Al}_{2} \mathrm{O}_{3}$ & $\mathrm{Fe}_{2} \mathrm{O}_{3}$ & $\mathrm{CaO}$ & $\mathrm{SO}_{3}$ & MgO & $\mathrm{K}_{2} \mathrm{O}$ & $\mathrm{SiO}_{2}$ & Water & KDP & Gypsum \\
\hline $1200-40 \%$ & 12.19 & 1.18 & 31.23 & 24.07 & 25.06 & 0.19 & 5.69 & 29.4 & 17.03 & 3.73 \\
\hline $1200-50 \%$ & 8.65 & 1.22 & 25.29 & 18.72 & 40.87 & 0.11 & 4.85 & 29.6 & 27.79 & 2.94 \\
\hline $1200-60 \%$ & 5.32 & 1.36 & 20.08 & 14.22 & 54.36 & 0.06 & 4.35 & 29.7 & 36.96 & 2.26 \\
\hline $1200-70 \%$ & 3.05 & 1.61 & 16.08 & 12.48 & 62.68 & 0.03 & 3.88 & 29.8 & 42.62 & 1.85 \\
\hline $1200-80 \%$ & 2.05 & 1.64 & 13.58 & 10.05 & 68.03 & 0.06 & 4.42 & 29.9 & 46.23 & 1.59 \\
\hline $1250-40 \%$ & 13.37 & 1.18 & 29.83 & 25.24 & 24.81 & 0.13 & 5.01 & 29.4 & 16.87 & 3.73 \\
\hline $1250-50 \%$ & 11.98 & 1.38 & 24.95 & 15.77 & 40.42 & 0.14 & 4.96 & 29.6 & 27.48 & 2.95 \\
\hline $1250-60 \%$ & 8.78 & 1.59 & 20.43 & 10.13 & 52.84 & 0.08 & 5.72 & 29.7 & 35.93 & 2.33 \\
\hline $1250-70 \%$ & 3.81 & 1.63 & 15.25 & 7.76 & 66.45 & 0.04 & 4.85 & 29.8 & 45.18 & 1.66 \\
\hline $1250-80 \%$ & 2.82 & 1.76 & 12.55 & 4.45 & 73.54 & 0.08 & 4.61 & 29.9 & 50.01 & 1.31 \\
\hline $1300-40 \%$ & 25.18 & 1.26 & 32.13 & 8.89 & 24.66 & 0.21 & 6.93 & 29.4 & 16.77 & 3.73 \\
\hline $1300-50 \%$ & 19.85 & 1.54 & 28.81 & 6.73 & 34.69 & 0.17 & 7.6 & 29.6 & 23.59 & 3.23 \\
\hline $1300-60 \%$ & 14.24 & 2.39 & 22.96 & 4.73 & 46.33 & 0.23 & 8.46 & 29.7 & 27.78 & 2.65 \\
\hline $1300-70 \%$ & 7.75 & 2.48 & 20.79 & 5.78 & 54.56 & 0.07 & 8.26 & 29.8 & 37.11 & 2.25 \\
\hline $1300-80 \%$ & 4.48 & 2.55 & 16.52 & 1.81 & 66.14 & 0.05 & 8.24 & 29.9 & 44.98 & 1.68 \\
\hline $1350-40 \%$ & 26.13 & 1.42 & 35.00 & 4.76 & 23.85 & 0.13 & 8.17 & 29.4 & 16.22 & 3.78 \\
\hline $1350-50 \%$ & 19.24 & 1.63 & 30.49 & 3.26 & 36.01 & 0.08 & 8.81 & 29.6 & 24.48 & 3.17 \\
\hline $1350-60 \%$ & 14.46 & 1.72 & 23.82 & 3.89 & 47.03 & 0.13 & 8.58 & 29.7 & 31.97 & 2.63 \\
\hline $1350-70 \%$ & 7.17 & 2.18 & 19.19 & 3.84 & 58.57 & 0.07 & 8.68 & 29.8 & 41.19 & 2.05 \\
\hline $1350-80 \%$ & 7.99 & 2.97 & 15.48 & 2.14 & 62.67 & 0.16 & 8.04 & 29.9 & 42.86 & 1.84 \\
\hline
\end{tabular}

(4) Grinding and molding

SAC-MKPC clinker samples were pulverized by a clinker grinding mill, and the clinker powder's diameter was controlled to less than $45 \mathrm{um}$. The SAC-MKPC cementitious composite material was mixed with water to form a slurry, and the slurry was poured into a standard mold $(20 \mathrm{~mm} \times 20 \mathrm{~mm} \times 20 \mathrm{~mm})$. Standard test blocks were prepared and cured according to Chinese national standard GB50204-2002 [29]. A batch of six $20 \mathrm{~mm} \times$ $20 \mathrm{~mm} \times 20 \mathrm{~mm}$ paste specimens were made for compressive strength testing.

\section{Results and Discussion}

\subsection{Mineralogical Composition of the SAC-MKPC Clinker}

The theoretical $\mathrm{MgO}$ content and calcination temperature are two key factors in the clinker and hydration properties of the paste, and they affect the physical and mechanical properties. The XRD patterns of the SAC-MKPC clinker system at different calcination temperatures and raw material ratios are shown in Figures 4-7. Figures 4-7 present the XRD patterns of the different theoretical MgO contents in the SAC-MKPC clinker system at the same calcination temperatures. The final clinker was mainly composed of ye'elimite $\left(\mathrm{C}_{4} \mathrm{~A}_{3} \overline{\mathrm{S}}\right)$, periclase $(\mathrm{MgO})$, and dicalcium silicate $\left(\mathrm{C}_{2} \mathrm{~S}\right)$. A small amount of magnesia aluminum spinel $\left(\mathrm{MgAl}_{2} \mathrm{O}_{4}\right)$, anhydrite $\left(\mathrm{CaSO}_{4}\right)$, and akermanite $\left(\mathrm{Ca}_{3} \mathrm{MgSi}_{2} \mathrm{O}_{8}\right)$ was observed in all samples, which indicated that all $\mathrm{Ca}(\mathrm{OH})_{2}, \mathrm{MgSO}_{4}, \mathrm{MgSO}_{3}, \mathrm{Al}_{2} \mathrm{O}_{3}, \mathrm{CaCO}_{3}$, and $\mathrm{SiO}_{2}$ in the raw materials had been chemically combined after calcination. Moreover, the peak intensities of anhydrite decreased with an increasing calcination temperature. When the calcination temperature was lower than $1250{ }^{\circ} \mathrm{C}$, periclase $(\mathrm{MgO})$, dicalcium silicate $\left(\mathrm{Ca}_{2} \mathrm{SiO}_{4}\right)$, residual anhydrite $\left(\mathrm{CaSO}_{4}\right)$, less mineral-phase magnesia alumina spinel $\left(\mathrm{MgAl}_{2} \mathrm{O}_{4}\right)$, and merwinite $\left(\mathrm{Ca}_{3} \mathrm{MgSi}_{2} \mathrm{O}_{8}\right)$ were produced in the SAC-MKPC clinker system, but ye'elimite was not produced. With an increase in the calcination temperature, ye'elimite appeared in 
the sample prepared at $1300^{\circ} \mathrm{C}$. The XRD patterns of SAC-MKPC clinker powders with calcination temperatures between 1300 and $1350{ }^{\circ} \mathrm{C}$ are shown in Figures 6 and 7. The final clinker was mainly composed of ye'elimite $\left(\mathrm{C}_{4} \mathrm{~A}_{3} \overline{\mathrm{S}}\right)$, periclase $(\mathrm{MgO})$, and dicalcium silicate $\left(\mathrm{C}_{2} \mathrm{~S}\right)$. A small amount of magnesia aluminum spinel $\left(\mathrm{MgAl}_{2} \mathrm{O}_{4}\right)$ and akermanite $\left(\mathrm{Ca}_{3} \mathrm{MgSi}_{2} \mathrm{O}_{8}\right)$ was observed in the calcination products. An abundance of periclase $(\mathrm{MgO})$ and ye'elimite and a small amount of $\mathrm{MgAl}_{2} \mathrm{O}_{4}$ and $\mathrm{Ca}_{3} \mathrm{MgSi}_{2} \mathrm{O}_{8}$ were visible. $\mathrm{MgAl}_{2} \mathrm{O}_{4}$ was one of the mineral phases of the aluminum slag, and the residual anhydrite $\left(\mathrm{CaSO}_{4}\right)$ had decomposed completely.

According to the XRD patterns of SAC-MKPC clinker powders with calcination temperatures between 1200 and $1350{ }^{\circ} \mathrm{C}$ under different raw material ratios, the desired mineral $\left(\mathrm{C}_{4} \mathrm{~A}_{3} \overline{\mathrm{S}}, \mathrm{MgO}\right)$ was produced. Meanwhile, aluminum spinel $\left(\mathrm{MgAl}_{2} \mathrm{O}_{4}\right)$ and akermanite $\left(\mathrm{Ca}_{3} \mathrm{MgSi}_{2} \mathrm{O}_{8}\right)$ were also found in the SAC-MKPC clinker system. Compared with the magnesium phosphate cementitious material, SAC-MKPC clinker can be prepared in a relatively low-temperature region.
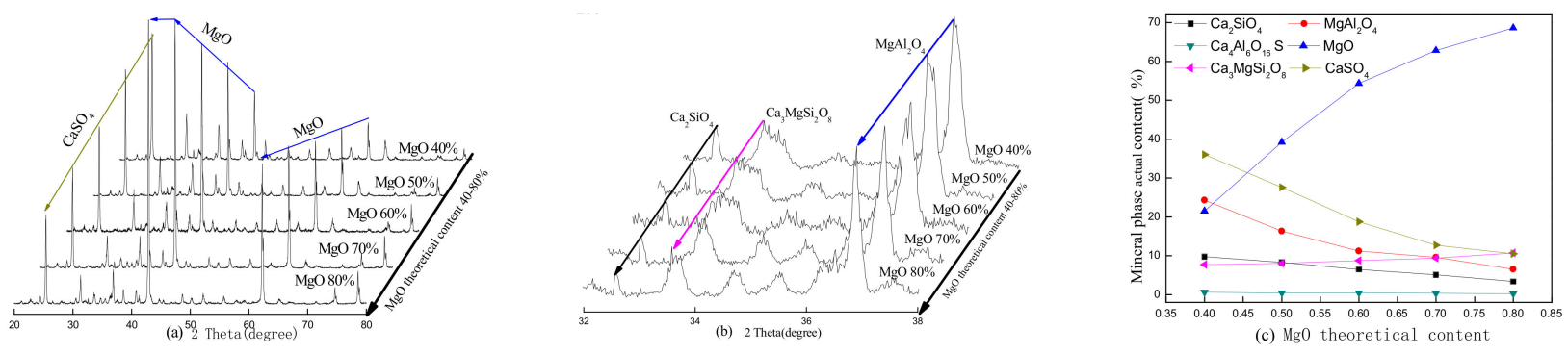

Figure 4. XRD patterns of the SAC-MKPC clinker with $\mathrm{MgO}$ theoretical content at $1200{ }^{\circ} \mathrm{C}$ : (a) main phase; (b) minor phase; and (c) mineral phase actual content.
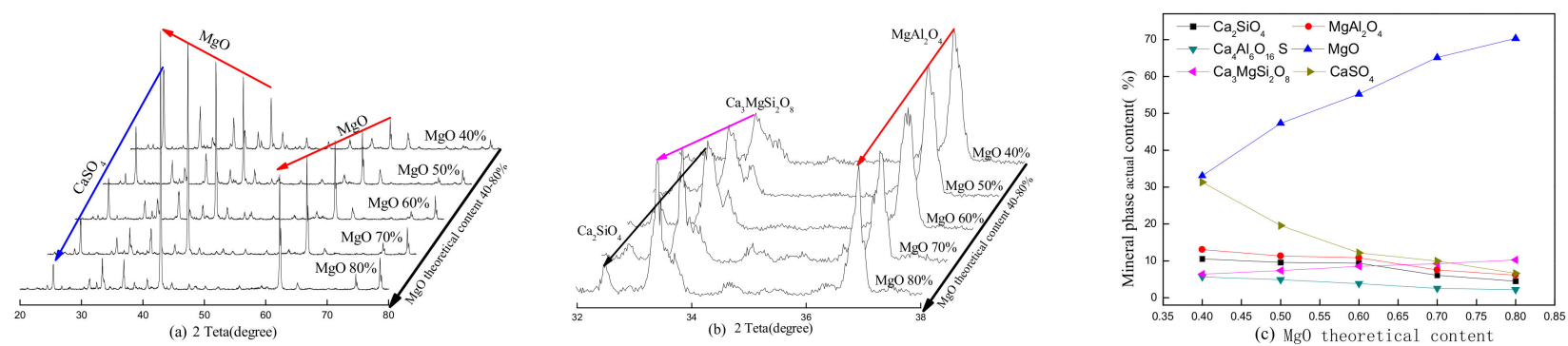

Figure 5. XRD patterns of the SAC-MKPC clinker with $\mathrm{MgO}$ theoretical content at $1250{ }^{\circ} \mathrm{C}$ : (a) main phase; (b) minor phase; and (c) mineral phase actual content.
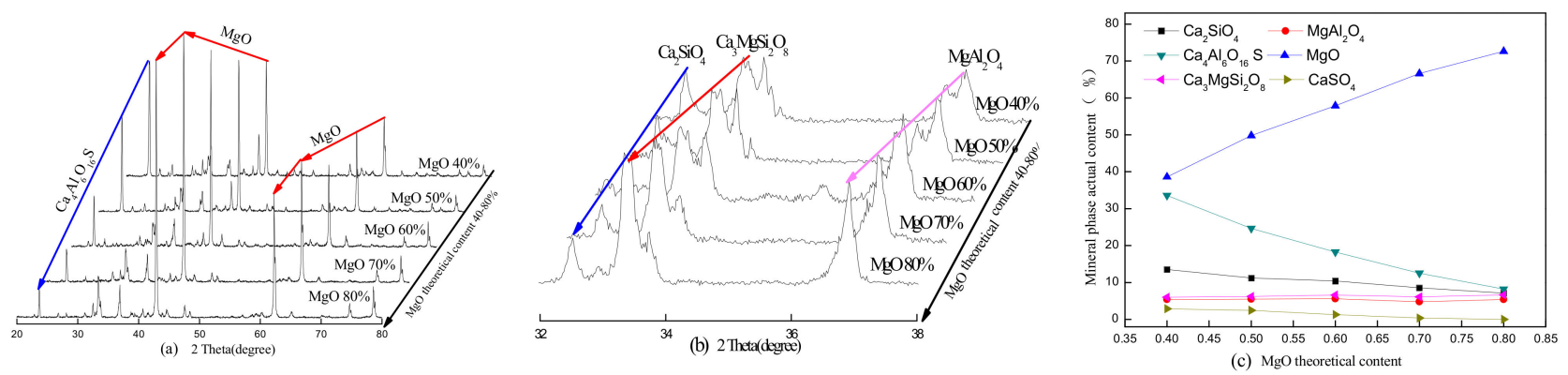

Figure 6. XRD patterns of the SAC-MKPC clinker with $\mathrm{MgO}$ theoretical content at $1300{ }^{\circ} \mathrm{C}$ : (a) main phase; (b) minor phase; and (c) mineral phase actual content. 

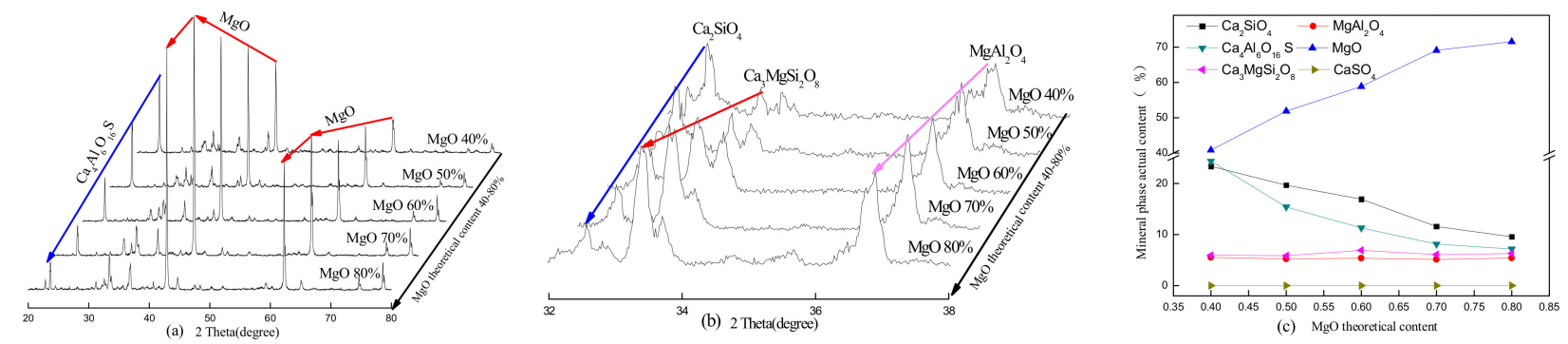

Figure 7. XRD patterns of the SAC-MKPC clinker with $\mathrm{MgO}$ theoretical content at $1350{ }^{\circ} \mathrm{C}$ : (a) main phase; (b) minor phase; and (c) mineral phase actual content.

\subsection{Analysis of Hydration Products}

To explore the possible mineral types of the SAC-MKPC hydration reaction, XRD tests of SAC-MKPC hydration were carried out. Figure 8 shows the XRD pattern of the SAC-MKPC pastes produced with industrial solid wastes at $1300{ }^{\circ} \mathrm{C}$ and cured for $28 \mathrm{~d}$. The SAC-MKPC clinker was selected with a MgO theoretical content of $60 \%$ and the $\mathrm{M} / \mathrm{P}$ was 5 . The results show that the main minerals in the SAC-MKPC hydration reaction are K-struvite $\left(\mathrm{MgKPO}_{4} \cdot 6 \mathrm{H}_{2} \mathrm{O}\right)$, ettringite $\left(3 \mathrm{CaO} \cdot \mathrm{Al}_{2} \mathrm{O}_{3} \cdot 3 \mathrm{CaSO}_{4} \cdot 32 \mathrm{H}_{2} \mathrm{O}\right)$, and $\mathrm{MgO}$, and unreacted ye'elimite $\left(\mathrm{C}_{4} \mathrm{~A}_{3} \overline{\mathrm{S}}\right)$ and magnesia alumina spinel $\left(\mathrm{MgAl}_{2} \mathrm{O}_{4}\right)$ were found in the XRD patterns. Hence, the goal of using coal gangue, carbide slag, magnesium desulfurization slag, and aluminum slag as raw materials to prepare the sulphoaluminate magnesium-potassium phosphate cementitious composite material was initially achieved.

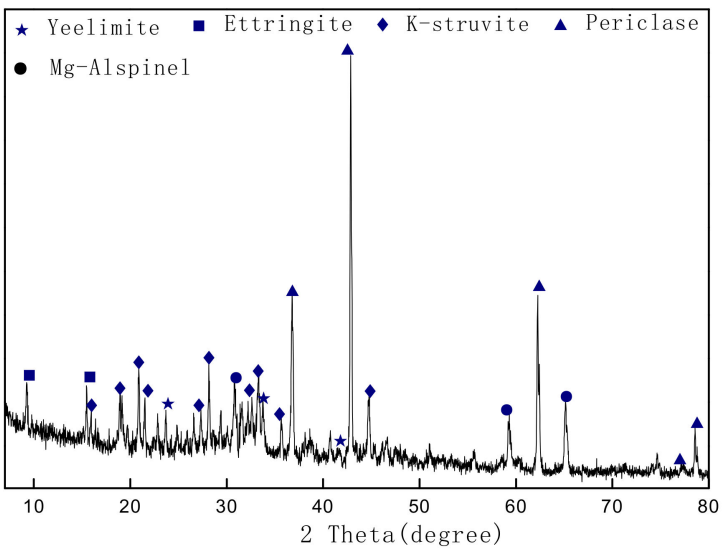

Figure 8. XRD pattern of SAC-MKPC paste after 28 days of curing.

The TG-DSC results of the SAC-MKPC pastes prepared with calcination temperatures between 1200 and $1350{ }^{\circ} \mathrm{C}$ and cured for 28 days are shown in Figure 9. The hydration products of SAC-MKPC include hydrated calcium aluminate sulfate (AFt-ettringite and AFm-monosulfate), $\mathrm{MgKPO}_{4} \cdot 6 \mathrm{H}_{2} \mathrm{O}$, aluminum glue, iron glue, and calcium silicate hydrate gel according to previous studies [30-32]. Meanwhile, unreacted ye'elimite, $\mathrm{MgO}$, anhydrite, and $\mathrm{KH}_{2} \mathrm{PO}_{4}$ are also present. Hence, the thermal mass loss of the hydration products of SAC-MKPC can be divided into two main stages. The first stage's temperature range is from 30 to $200{ }^{\circ} \mathrm{C}$, and $\mathrm{MgKPO}_{4} \cdot 6 \mathrm{H}_{2} \mathrm{O}$, Aft, iron glue, and $\mathrm{CaSO}_{4} \cdot 2 \mathrm{H}_{2} \mathrm{O}$ lose water. The second stage's temperature range is from 30 to $200{ }^{\circ} \mathrm{C}$, and unreacted $\mathrm{KH}_{2} \mathrm{PO}_{4}$ and aluminum glue lose water. The main reactions as follows:

First stage

$$
\begin{gathered}
\mathrm{MgKPO}_{4} \cdot 6 \mathrm{H}_{2} \mathrm{O} \stackrel{60-200{ }^{\circ} \mathrm{C}}{\longrightarrow} \mathrm{MgKPO}_{4}+6 \mathrm{H}_{2} \mathrm{O} \uparrow \\
3 \mathrm{CaO} \cdot \mathrm{Al}_{2} \mathrm{O}_{3} \cdot 3 \mathrm{CaSO}_{4} \cdot 32 \mathrm{H}_{2} \mathrm{O} \stackrel{>90^{\circ} \mathrm{C}}{\longrightarrow} 3 \mathrm{CaO} \cdot \mathrm{Al}_{2} \mathrm{O}_{3} \cdot \mathrm{CaSO}_{4} \cdot 12 \mathrm{H}_{2} \mathrm{O}+20 \mathrm{H}_{2} \mathrm{O} \uparrow
\end{gathered}
$$




$$
\begin{gathered}
\mathrm{CaSO}_{4} \cdot 2 \mathrm{H}_{2} \mathrm{O} \stackrel{110-190{ }^{\circ} \mathrm{C}}{\longrightarrow} \mathrm{CaSO}_{4} \cdot \frac{1}{2} \mathrm{H}_{2} \mathrm{O}+\frac{3}{2} \mathrm{H}_{2} \mathrm{O} \uparrow \\
\mathrm{Fe}_{2} \mathrm{O}_{3} \cdot 3 \mathrm{H}_{2} \mathrm{O}(\mathrm{gel}) \stackrel{150-160{ }^{\circ} \mathrm{C}}{\longrightarrow} \mathrm{Fe}_{2} \mathrm{O}_{3}+3 \mathrm{H}_{2} \mathrm{O} \uparrow
\end{gathered}
$$

Second stage

$$
\begin{gathered}
\mathrm{KH}_{2} \mathrm{PO}_{4} \stackrel{>200{ }^{\circ} \mathrm{C}}{\longrightarrow} \mathrm{KPO}_{3}+\mathrm{H}_{2} \mathrm{O} \uparrow \\
\mathrm{Al}_{2} \mathrm{O}_{3} \cdot 3 \mathrm{H}_{2} \mathrm{O}(\text { gel }) \stackrel{>300{ }^{\circ} \mathrm{C}}{\longrightarrow} \mathrm{Al}_{2} \mathrm{O}_{3}+3 \mathrm{H}_{2} \mathrm{O} \uparrow \\
\mathrm{CaSO}_{4} \cdot \frac{1}{2} \mathrm{H}_{2} \mathrm{O} \stackrel{2220^{\circ} \mathrm{C}}{\longrightarrow} \mathrm{CaSO}_{4}+\frac{1}{2} \mathrm{H}_{2} \mathrm{O} \uparrow
\end{gathered}
$$

As shown by the TG-DTG outputs of the SAC-MKPC hydration product, the hydration product starts to decompose at $60^{\circ} \mathrm{C}$, and the decomposition rate of the hydration product becomes faster as the temperature increases to $90 \sim 110{ }^{\circ} \mathrm{C}$. Only one obvious instance of weight loss below $200^{\circ} \mathrm{C}$ can be observed in the curves and can mainly be attributed to the decomposition of struvite and AFt. When the temperature increased to $230^{\circ} \mathrm{C}$, the hydration products of SAC-MKPC prepared by the T1200-1250 ${ }^{\circ} \mathrm{C}$ with $\mathrm{MgO}$ with a theoretical content of $40 \%, 50 \%$, and $60 \%$ showed a small endothermic peak, and endothermic peaks were not observed for the other samples in the temperature range. When the temperature exceeded $400^{\circ} \mathrm{C}$, the mass loss of the hydration product remained stable.
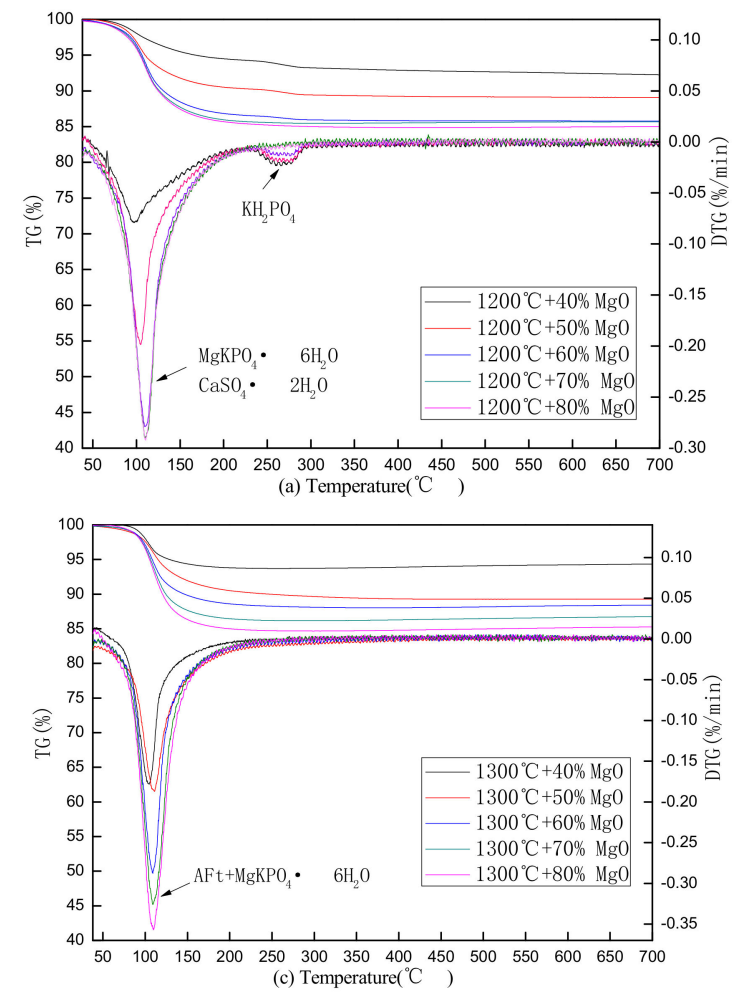
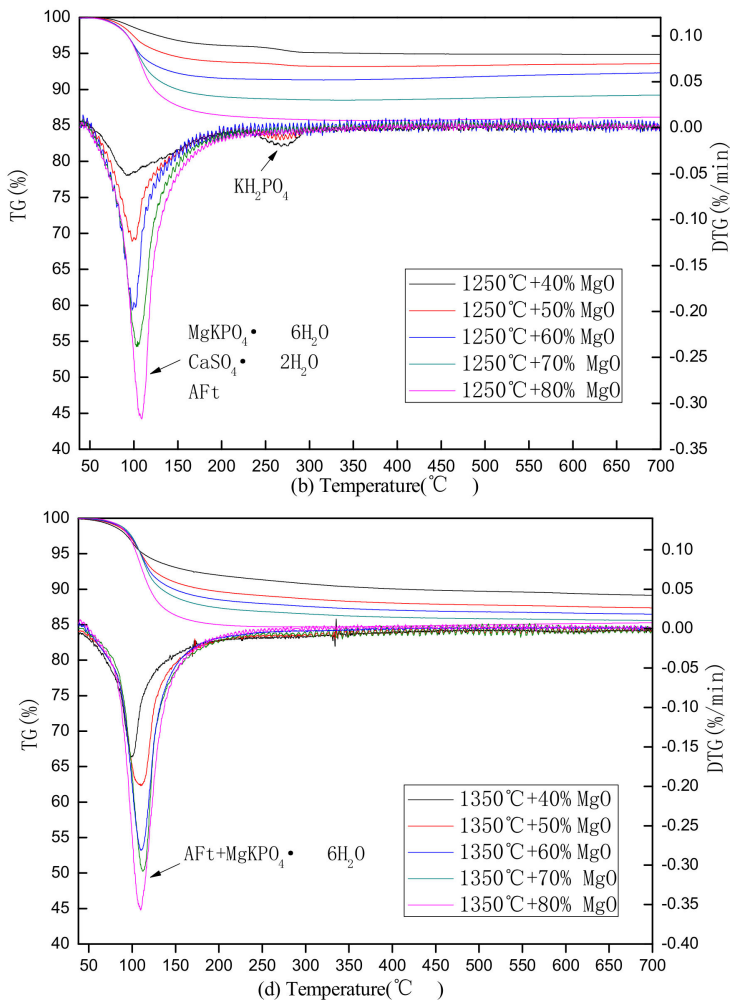

Figure 9. TG-DTG outputs of the SAC-MKPC hydration product at 28 days: (a) $120{ }^{\circ} \mathrm{C}$; (b) $1250{ }^{\circ} \mathrm{C}$; (c) $1300^{\circ} \mathrm{C}$; (d) $1350{ }^{\circ} \mathrm{C}$.

Figure 9a shows the TG-DTG results of the SAC-MKPC pastes prepared with a calcination temperature of $1200{ }^{\circ} \mathrm{C}$ and cured for 28 days. The endothermic peaks of the hydration products appeared at $60-200{ }^{\circ} \mathrm{C}$, which indicates the main phase decomposition of $\mathrm{MgKPO}_{4} \cdot 6 \mathrm{H}_{2} \mathrm{O}$ and $\mathrm{CaSO}_{4} \cdot 2 \mathrm{H}_{2} \mathrm{O}$. Another obvious instance of weight loss at $230-260{ }^{\circ} \mathrm{C}$ can be observed in the curves and can mainly be attributed to the decomposition of unreacted $\mathrm{KH}_{2} \mathrm{PO}_{4}$. Figure $9 \mathrm{~b}$ shows the TG-DTG results of the SAC-MKPC pastes prepared with a calcination temperature of $1250{ }^{\circ} \mathrm{C}$ and cured for 28 days. The endothermic peak of the hydration product was similar to that in Figure $9 \mathrm{~b}$ at $60-200{ }^{\circ} \mathrm{C}$ and at $230-260^{\circ} \mathrm{C}$, 
which indicates the main phase decomposition of $\mathrm{MgKPO}_{4} \cdot 6 \mathrm{H}_{2} \mathrm{O}, \mathrm{CaSO}_{4} \cdot 2 \mathrm{H}_{2} \mathrm{O}, \mathrm{AFt}$, and unreacted $\mathrm{KH}_{2} \mathrm{PO}_{4}$. Compared with Figure $9 \mathrm{a}$, b, the endothermic peaks of the hydration products that appeared at $60-200{ }^{\circ} \mathrm{C}$ were similar to those in Figure $9 \mathrm{c}, \mathrm{d}$. However, there was no obvious endothermic peak above $200{ }^{\circ} \mathrm{C}$, which indicated that unreacted $\mathrm{KH}_{2} \mathrm{PO}_{4}$ was nonexistent in the hydration products of SAC-MKPC.

Table 5 summarizes the mass loss $\left(\mathrm{WL}_{30-200}{ }^{\circ} \mathrm{C}\right.$ and $\left.\mathrm{WL}_{200-700}{ }^{\circ} \mathrm{C}\right)$ and the most intense temperature peak of mass loss (TPWL) in the different temperature ranges. When the calcination temperature was $1200-1250^{\circ} \mathrm{C}$ and the $\mathrm{MgO}$ theoretical content was $40-50 \%$, the most intense TPWL of the SAC-MKPC hydration products was low, at $\sim 100{ }^{\circ} \mathrm{C}$. When the calcination temperature was $1300-1350{ }^{\circ} \mathrm{C}$ with the same $\mathrm{MgO}$ theoretical content, the TPWL of the SAC-MKPC hydration products increased slightly, and the TPWL exceeded $100{ }^{\circ} \mathrm{C}$ and extended to $104^{\circ} \mathrm{C}$. The TPWL reached $110^{\circ} \mathrm{C}$ with an increase in the theoretical $\mathrm{MgO}$ content at the same calcination temperature because more $\mathrm{MgKPO}_{4} \cdot 6 \mathrm{H}_{2} \mathrm{O}$ formed in the hydration product.

Table 5. TG results of the SAC-MKPC hydration product at 28 days.

\begin{tabular}{|c|c|c|c|c|c|}
\hline Sample & $1200-40 \%$ & $1200-50 \%$ & $1200-60 \%$ & $1200-70 \%$ & $1200-80 \%$ \\
\hline $\mathrm{TPWL},{ }^{\circ} \mathrm{C}$ & 98 & 102.5 & 106 & 107.5 & 108 \\
\hline WL30-200 ${ }^{\circ} \mathrm{C}$, wt.\% & 5.51 & 9.48 & 13.16 & 14.04 & 14.31 \\
\hline WL200-700 ${ }^{\circ} \mathrm{C}$, wt. $\%$ & 2.24 & 1.45 & 1.08 & 0.87 & 0.68 \\
\hline Sample & $1250-40 \%$ & $1250-50 \%$ & $1250-60 \%$ & $1250-70 \%$ & $1250-80 \%$ \\
\hline TPWL, ${ }^{\circ} \mathrm{C}$ & 92.5 & 97.5 & 101.5 & 105 & 108 \\
\hline WL30-200 ${ }^{\circ} \mathrm{C}$, wt.\% & 4.87 & 7.16 & 8.45 & 11.02 & 13.59 \\
\hline WL200-700 ${ }^{\circ} \mathrm{C}$, wt. $\%$ & 2.15 & 1.09 & 0.75 & 0.45 & 0.25 \\
\hline Sample & $1300-40 \%$ & $1300-50 \%$ & $1300-60 \%$ & $1300-70 \%$ & $1300-80 \%$ \\
\hline TPWL, ${ }^{\circ} \mathrm{C}$ & 103 & 105 & 106.5 & 107.5 & 108 \\
\hline WL30-200 ${ }^{\circ} \mathrm{C}$, wt. $\%$ & 6.19 & 9.49 & 11.41 & 13.55 & 14.99 \\
\hline WL200-700 ${ }^{\circ} \mathrm{C}$, wt. $\%$ & 1.54 & 1.24 & 0.86 & 0.53 & 0.46 \\
\hline Sample & $1350-40 \%$ & $1350-50 \%$ & $1350-60 \%$ & $1350-70 \%$ & $1350-80 \%$ \\
\hline TPWL, ${ }^{\circ} \mathrm{C}$ & 102 & 104 & 106 & 107 & 108 \\
\hline WL30-200 ${ }^{\circ} \mathrm{C}$, wt. $\%$ & 8.02 & 10.33 & 11.18 & 12.63 & 14.61 \\
\hline WL200-700 ${ }^{\circ} \mathrm{C}$, wt. $\%$ & 1.43 & 1.13 & 0.74 & 0.58 & 0.41 \\
\hline
\end{tabular}

Note: TPWL, temperature peak of mass loss, ${ }^{\circ} \mathrm{C} ; \mathrm{WL}_{30-200}{ }^{\circ} \mathrm{C}, 30-200{ }^{\circ} \mathrm{C}$ mass loss percentage; $\mathrm{WL}_{200-700}{ }^{\circ} \mathrm{C}, 200-700{ }^{\circ} \mathrm{C}$ mass loss percentage.

Table 5 shows that all samples had an increase in mass loss with increasing theoretical $\mathrm{MgO}$ values at $30-200{ }^{\circ} \mathrm{C}$, but all samples had a decrease in mass loss with increasing theoretical $\mathrm{MgO}$ values at $200-700{ }^{\circ} \mathrm{C}$. At $30-200{ }^{\circ} \mathrm{C}$, the $\mathrm{MgO}$ theoretical content was $60-80 \%$, the largest mass loss of the SAC-MKPC hydration products occurred when the clinker was prepared at $1300^{\circ} \mathrm{C}$, followed by $1350{ }^{\circ} \mathrm{C}$ and $1200^{\circ} \mathrm{C}$, and the smallest mass loss occurred at $1250^{\circ} \mathrm{C}$. Therefore, the sample in which the $\mathrm{MgO}$ theoretical content was $60-80 \%$ at $1300{ }^{\circ} \mathrm{C}$ showed the highest AFt and $\mathrm{MgKPO}_{4} \cdot 6 \mathrm{H}_{2} \mathrm{O}$ content compared with that in the other three samples. However, the mass loss of the SAC-MKPC hydration products when the clinker was prepared at $1200{ }^{\circ} \mathrm{C}$ was higher than that prepared at $1250{ }^{\circ} \mathrm{C}$. Combined with the analysis of the mineral composition of the SAC-MKPC clinker in Section 3.1, the anhydrate content decreased with increasing temperature, and its content was highest, which was observed in the sample at $1200{ }^{\circ} \mathrm{C}$, and the AFt phase was not generated by $3 \mathrm{CaO} \cdot 3 \mathrm{Al}_{2} \mathrm{O}_{3} \cdot \mathrm{CaSO}_{4}$ hydration; hence, the hydration product phase at $1250{ }^{\circ} \mathrm{C}$ was lower. At $200-700{ }^{\circ} \mathrm{C}$, the largest mass loss of the SAC-MKPC hydration product occurred at $1200{ }^{\circ} \mathrm{C}$, followed by $1250{ }^{\circ} \mathrm{C}$ and $1300^{\circ} \mathrm{C}$, and the smallest mass loss occurred at $1350{ }^{\circ} \mathrm{C}$. The main mass loss was caused by the decomposition of unreacted $\mathrm{KH}_{2} \mathrm{PO}_{4}$ in the same temperature range.

\subsection{SEM-EDS Analysis}

In the study of the microstructure of the SAC and MKPC hydration product, the calcium sulfoaluminate hydrate showed many structural forms, including fine needles, thick needles, 
and tubular, cylindrical, and hexagonal shapes. The aluminum glue $\left(\mathrm{Al}_{2} \mathrm{O}_{3} \cdot 3 \mathrm{H}_{2} \mathrm{O}(\right.$ gel $\left.)\right)$ was pom-pom- or needle-shaped [33], and the $\mathrm{MgKPO}_{4} \cdot 6 \mathrm{H}_{2} \mathrm{O}$ had a block or plate crystal structure [34,35].

Figure 10 shows the SEM micrographs of the SAC-MKPC and the EDS results (curing age: 28 days). Large crystals in a prism-like shape, a cylindrical shape, and a pom-pom shape were found in the paste (Figure 10). Energy spectrum analysis for four different surface areas (A, B, C, D) was invested, A area is a prism-like shape, B area is a skeleton structure, $\mathrm{C}$ area is a block shape, $\mathrm{D}$ area is a pom-pom shape. Elemental distribution in selected areas is given in Table 6 . The main elements $(\mathrm{Ca}, \mathrm{S}, \mathrm{Al}, \mathrm{Fe}$, and $\mathrm{O})$ were visible in area A. The molar ratios (m.r.) of $\mathrm{Ca}(\mathrm{Al}+\mathrm{Fe}): \mathrm{S}$ were $4.74: 1: 3.3$, which is close to 4:1:3, implying the existence of AFt [32]. According to the EDS results of area A and the XRD results mentioned above, these crystals with a regular columnar structure were proven to be AFt. Area B showed a solid block structure, which was covered with a thin plate crystal. According to the EDS results for area $\mathrm{B}$, the main elements $(\mathrm{Mg}, \mathrm{K}, \mathrm{P}$, and $\mathrm{O})$ were visible in area $\mathrm{B}$. This indicates that the molar ratio of $\mathrm{P}: \mathrm{K}: \mathrm{Mg}: \mathrm{O}$ was 1.9:1.0:(1 + 8.72):23.55, which is close to the theoretical value (1:1:1:10) of the molar ratios of the $\mathrm{MgO}$ skeleton structure covered with $\mathrm{MgKPO}_{4} \cdot 6 \mathrm{H}_{2} \mathrm{O}$ crystals. According to the EDS results for area $\mathrm{C}$, the main elements were $\mathrm{Mg}, \mathrm{P}, \mathrm{K}$, and $\mathrm{Ca}$ in area $\mathrm{C}$, and the molar ratio (m.r.) of P:K:Mg was 1.26:1:0.92, which is close to the theoretical value (1:1:1) of the molar ratios of K-struvite $\left(\mathrm{MgKPO}_{4} \cdot 6 \mathrm{H}_{2} \mathrm{O}\right)$. For area $\mathrm{D}$, the surface of the bulk was covered by amorphous material that had a complicated element composition, which included $\mathrm{Ca}, \mathrm{Al}, \mathrm{P}$, and a small amount of elemental $\mathrm{Fe}, \mathrm{S}$, and Si. This was mostly a cementation product of $\mathrm{MgKPO}_{4} \cdot 6 \mathrm{H}_{2} \mathrm{O}$, $3 \mathrm{CaO} \cdot \mathrm{Al}_{2} \mathrm{O}_{3} \cdot 3 \mathrm{CaSO}_{4} \cdot 32 \mathrm{H}_{2} \mathrm{O}$, aluminum glue, iron glue, silica gel, calcium phosphate, and other minerals. The bulk could be glued together through the amorphous material to form a relatively dense structure.

Table 6. Elemental distribution in selected areas.

\begin{tabular}{|c|c|c|c|c|c|c|c|c|}
\hline \multirow{2}{*}{ Element } & \multicolumn{2}{|c|}{ A } & \multicolumn{2}{|c|}{ B } & \multicolumn{2}{|c|}{ C } & \multicolumn{2}{|c|}{ D } \\
\hline & at $\%$ & m.r. & at $\%$ & m.r. & at $\%$ & m.r. & at $\%$ & m.r. \\
\hline C & 1.51 & 2.88 & - & - & - & - & 0.58 & 1.10 \\
\hline $\mathrm{O}$ & 43.83 & 62.68 & 49.17 & 61.94 & 43.34 & 3.26 & 42.23 & 60.02 \\
\hline $\mathrm{Al}$ & 3.28 & 2.78 & 0.48 & 0.36 & 0.95 & 0.76 & 18.88 & 15.91 \\
\hline $\mathrm{Si}$ & - & - & 0.54 & 0.39 & - & - & 2.24 & 1.74 \\
\hline$S$ & 17.32 & 12.36 & 1.99 & 1.25 & - & - & 2.03 & 1.44 \\
\hline $\mathrm{Ca}$ & 31.09 & 17.75 & 1.61 & 0.81 & 4.47 & 2.42 & 29.01 & 16.49 \\
\hline $\mathrm{Fe}$ & 2.34 & 0.96 & 0.19 & 0.07 & - & - & 1.97 & 0.81 \\
\hline $\mathrm{Mg}$ & 0.63 & 0.59 & 33.25 & 27.57 & 19.61 & 15.07 & - & - \\
\hline $\mathrm{P}$ & - & - & 7.69 & 5.00 & 13.41 & 11.99 & 3.09 & 2.51 \\
\hline K & - & - & 5.09 & 2.63 & 18.22 & 11.00 & - & - \\
\hline
\end{tabular}




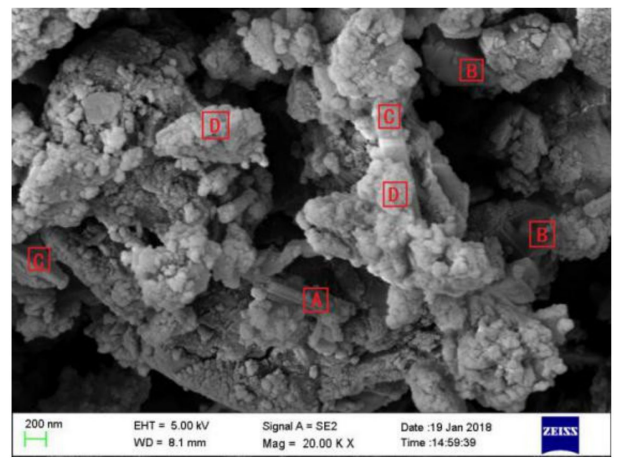

(a)

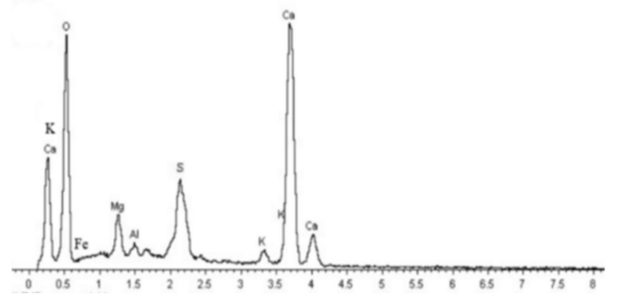

(b)
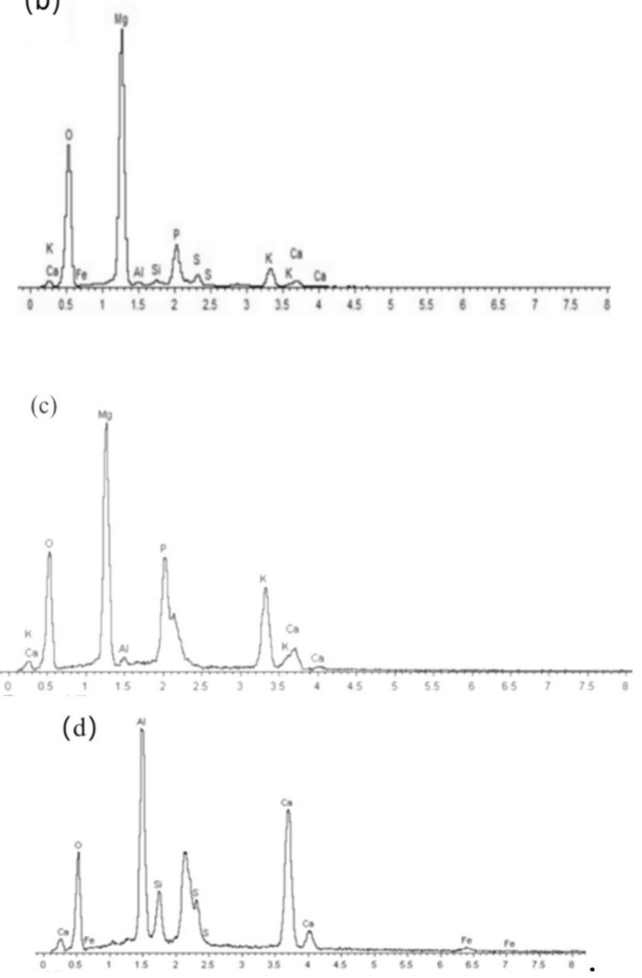

Figure 10. SEM micrographs of SAC-MKPC and EDS spectra (curing age: 28 days) (a. A area, b. B area, c. C area, d. D area).

\subsection{Mechanical Properties of the SAC-MKPC Paste}

The influence of the main-phase theoretical composition and the calcination temperature on the mechanical properties of the SAC-MKPC paste under different preparation conditions was investigated. The results are shown in Figures 11 and 12. 


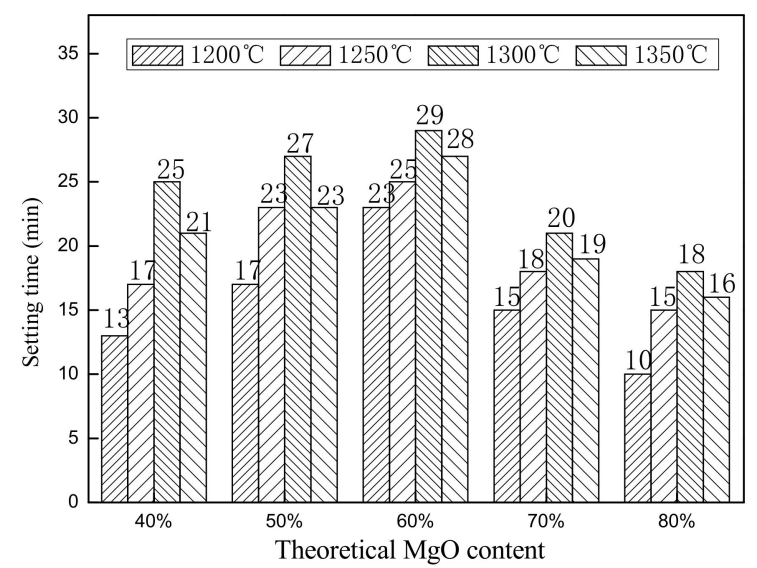

Figure 11. SAC-MKPC sample setting time.
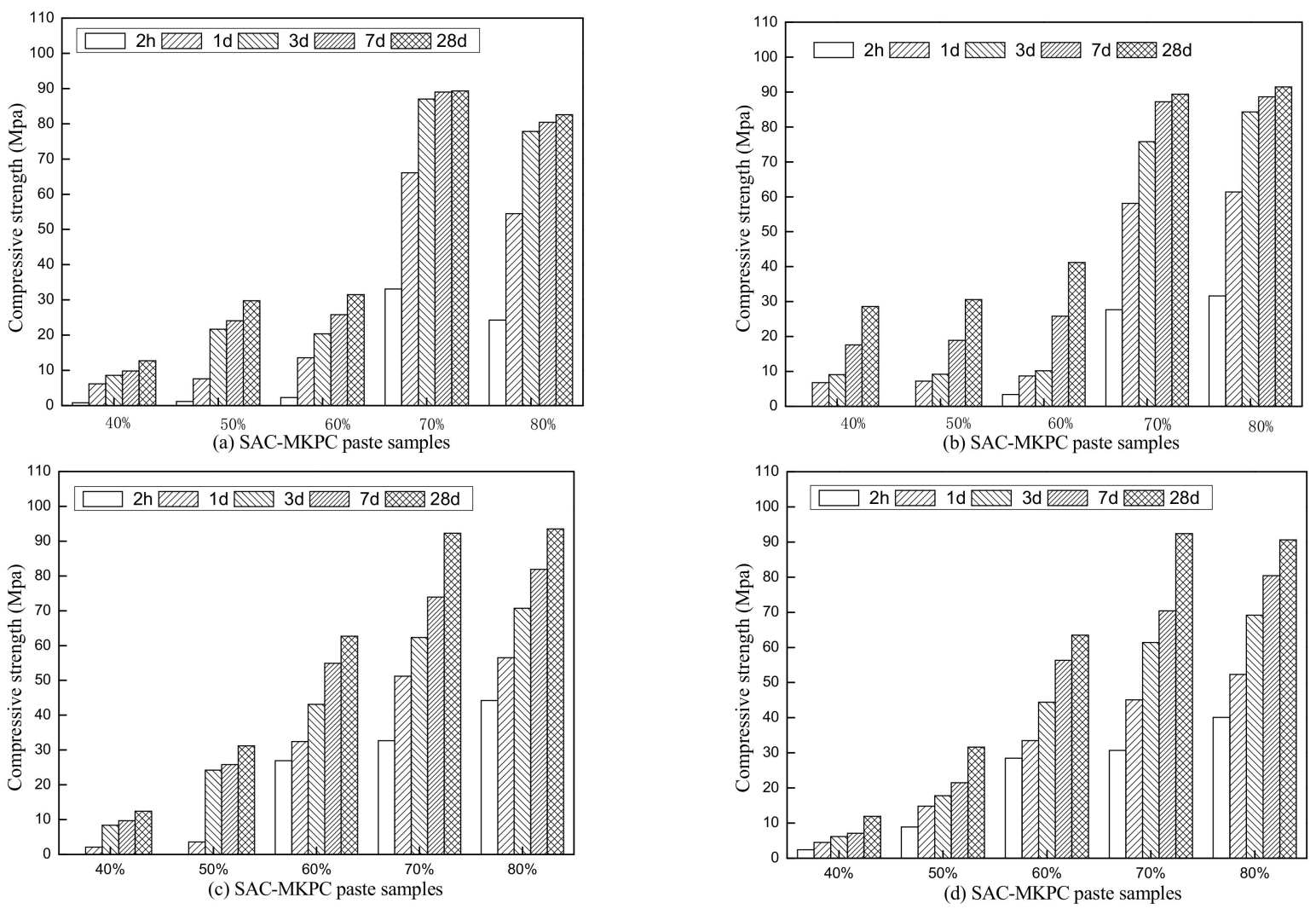

Figure 12. Compressive strength of SAC-MKPC samples at (a) $1200{ }^{\circ} \mathrm{C}$, (b) $1250{ }^{\circ} \mathrm{C}$, (c) $1300{ }^{\circ} \mathrm{C}$, and (d) $1350{ }^{\circ} \mathrm{C}$.

Figure 11 shows the setting time of the different SAC-MKPC samples from the VICAT measurements. When the theoretical content of $\mathrm{MgO}$ remained unchanged, the setting time increased initially and then decreased with an increase in the calcination temperature. Combined with the analysis of the mineral composition of the SAC-MKPC clinker in Section 3.1, when the calcination temperature was $1200^{\circ} \mathrm{C}$, the main mineral phases of the SAC-MKPC clinker were $\mathrm{MgO}, \mathrm{CaSO}_{4}$, a small amount of $\mathrm{Ca}_{2} \mathrm{SiO}_{4}$, and $\mathrm{MgAl}_{2} \mathrm{O}_{4}$ and $\mathrm{Ca}_{3} \mathrm{MgSi}_{2} \mathrm{O}_{8}$ impurities. The $\mathrm{MgO}$ of the SAC-MKPC clinker was light-burned magnesia, which has a higher activity and reacts rapidly with $\mathrm{KH}_{2} \mathrm{PO}_{4}$; hence, the setting time was short. As the calcination temperature continued to increase, the main mineral phases in the clinker transformed to $\mathrm{MgO}, 3 \mathrm{CaO} \cdot 3 \mathrm{Al}_{2} \mathrm{O}_{3} \cdot \mathrm{CaSO}_{4}$, and $\mathrm{Ca}_{2} \mathrm{SiO}_{4}$. The $\mathrm{MgAl}_{2} \mathrm{O}_{4}$, $\mathrm{Ca}_{3} \mathrm{MgSi}_{2} \mathrm{O}_{8}$, and $\mathrm{CaSO}_{4}$ phases decreased gradually and disappeared at $1300^{\circ} \mathrm{C}$. The $\mathrm{MgO}$ phase of the SAC-MKPC clinker was dead-burnt magnesia, which had a low reactivity 
and increased the setting time of the SAC-MKPC cementitious composite material under the calcination conditions. When the calcination temperature increased to $1350{ }^{\circ} \mathrm{C}$, the main mineral phases were $\mathrm{MgO}, \mathrm{Ca}_{2} \mathrm{SiO}_{4}$, and $3 \mathrm{CaO} \cdot 3 \mathrm{Al}_{2} \mathrm{O}_{3} \cdot \mathrm{CaSO}_{4}$ phases, and the total content of the main mineral phases increased slightly. Phases of $\mathrm{MgAl}_{2} \mathrm{O}_{4}$ and $\mathrm{Ca}_{3} \mathrm{MgSi}_{2} \mathrm{O}_{8}$ impurities of a lower content had little effect on the setting time. The setting time was similar to that of the pure SAC-MKPC slurry that was prepared for the calcination temperature at $1300{ }^{\circ} \mathrm{C}$.

When the calcination temperature remained unchanged, the setting time increased initially and then decreased with the increase in the theoretical content of $\mathrm{MgO}$. When the theoretical content of $\mathrm{MgO}$ reached the maximum, the setting time was the shortest. When the theoretical content of $\mathrm{MgO}$ in the SAC-MKPC clinker exceeded $60 \%$, the contact probability was higher between the $\mathrm{MgO}$ and the $\mathrm{KH}_{2} \mathrm{PO}_{4}$ dissolved in water, which resulted in a rapid acid-base reaction and the SAC-MKPC had the shortest setting time. When the theoretical content of $\mathrm{MgO}$ in the clinker was $40-60 \%$, the setting time increased gradually with an increase in the theoretical $\mathrm{MgO}$ content. The clinker contained a certain amount of $3 \mathrm{CaO} \cdot 3 \mathrm{Al}_{2} \mathrm{O}_{3} \cdot \mathrm{CaSO}_{4}$ and residual $\mathrm{Al}_{2} \mathrm{O}_{3}$ and $\mathrm{MgO} . \mathrm{Al}_{2} \mathrm{O}_{3}$ and $\mathrm{MgO}$ reacted with $\mathrm{KH}_{2} \mathrm{PO}_{4}$ in water, which increased the setting time gradually. The setting time of the SAC-MKPC composite material was closer to the hydration reaction time of $3 \mathrm{CaO} \cdot 3 \mathrm{Al}_{2} \mathrm{O}_{3} \cdot \mathrm{CaSO}_{4}$.

The compressive strength of the SAC-MKPC pastes prepared with different theoretical $\mathrm{MgO}$ contents at the same calcination temperature for various curing ages is presented in Figure 12. The compressive strength of samples with a theoretical $\mathrm{MgO}$ content of $40 \%$ and $50 \%$ was low at curing ages of $2 \mathrm{~h}, 1 \mathrm{~d}, 3 \mathrm{~d}, 7 \mathrm{~d}$, and $28 \mathrm{~d}$, respectively, and it did not reach the relevant national standard. The early (from $2 \mathrm{~h}$ to $3 \mathrm{~d}$ ) and later ( $28 \mathrm{~d}$ ) compressive strengths of the SAC-MKPC increased significantly with an increase in the $\mathrm{MgO}$ content. The content of theoretical $\mathrm{MgO}$ was $70 \%$ and $80 \%$. SAC-MKPC had a higher early strength and late strength. The compressive strength of the sample cured for $2 \mathrm{~h}$ exceeded $30 \mathrm{MPa}$ and the compressive strength of the sample cured for $1 \mathrm{~d}$ reached $80 \%$ of the $28 \mathrm{~d}$ compressive strength and later stabilized.

Figure 12 shows the effects of the calcination temperature on the compressive strengths of the SAC-MKPC with the same raw material composites. The compressive strength of the SAC-MKPC samples was low when the calcination temperature was $1200{ }^{\circ} \mathrm{C}$ and the theoretical MgO content of the SAC-MKPC clinker was less than $60 \%$. However, when the calcination temperature was unchanged, the theoretical $\mathrm{MgO}$ content was $70 \%$ and $80 \%$ and the 2-h compressive strength and late strength were higher than for other theoretical $\mathrm{MgO}$ contents. The 3-d compressive strength was close to the 28- $\mathrm{d}$ compressive strength, and the later strength was relatively stable.

\subsection{Water Resistance of the SAC-MKPC Paste}

To obtain the water resistance of the SAC-MKPC paste, the effects of $\mathrm{M} / \mathrm{P}$, ingredients, and curing conditions on the water resistance of SAC-MKPC were validated. According to the mechanical properties of the SAC-MKPC paste (Section 3.4) and using the clinker prepared at a calcination temperature of $1300{ }^{\circ} \mathrm{C}$ and with a theoretical $\mathrm{MgO}$ of $60 \%, 70 \%$, $80 \%$, and $100 \%$ as the foundational material, the $\mathrm{M} / \mathrm{P}$ was set to $3 / 1,5 / 1,7 / 1$, and $9 / 1$ using the above-described method (Section 2.2) to achieve the different water requirements. The compressive strength was obtained at different curing ages and under different curing conditions (air and water). To present the water resistance of the SAC-MKPC paste clearly, the strength retention rate [35-37] was defined as:

$$
\mathrm{K}=f / \mathrm{F}
$$

where $\mathrm{K}$ denotes the compressive strength retention rate of the sample, $f$ denotes the compressive strength of the sample at 28 days (MPa) in water, and F denotes the compressive strength of the sample at 28 days (MPa) after air curing. The compressive strength of the sample at 28 days (MPa) for different curing styles and strength retention were also shown in Table 7. 
Table 7. Strength retention rate under different curing conditions.

\begin{tabular}{ccccc}
\hline M/P & $\begin{array}{c}\text { Theoretical } \\
\text { MgO Content }\end{array}$ & $\begin{array}{c}\text { Air Curing for } \\
\text { 28 d (F/MPa) }\end{array}$ & $\begin{array}{c}\text { Water Curing } \\
\text { for 28 d (f/MPa) }\end{array}$ & $\begin{array}{c}\text { Strength Retention } \\
\text { Rate (K) }\end{array}$ \\
\hline \multirow{3}{*}{$3 / 1$} & $100 \%$ & 53.9 & 32.9 & 0.61 \\
& $80 \%$ & 67.5 & 43.8 & 0.65 \\
& $70 \%$ & 64.6 & 50.4 & 0.78 \\
$5 / 1$ & $60 \%$ & 48.3 & 46.9 & 0.97 \\
& $100 \%$ & 81.5 & 55.4 & 0.68 \\
& $80 \%$ & 91.4 & 76.5 & 0.83 \\
$7 / 1$ & $70 \%$ & 89.5 & 92.2 & 1.03 \\
& $60 \%$ & 53.5 & 57.8 & 1.08 \\
& $100 \%$ & 83.5 & 60.1 & 0.72 \\
& $80 \%$ & 92.6 & 86.1 & 0.93 \\
$9 / 1$ & $70 \%$ & 90.7 & 101.6 & 1.12 \\
& $60 \%$ & 55.2 & 64.6 & 1.17 \\
SAC & $100 \%$ & 42.2 & 24.5 & 0.58 \\
& $80 \%$ & 31.5 & 19.2 & 0.61 \\
& $70 \%$ & 25.2 & 24.7 & 0.98 \\
\hline
\end{tabular}

Figure 13 shows the compressive strength retention rate of SAC-MKPC with different $\mathrm{MgO}$ contents and the $\mathrm{M} / \mathrm{P}$ for two different curing schedules (air and water). When the $\mathrm{M} / \mathrm{P}$ was 5, 7, and 9, the theoretical $\mathrm{MgO}$ content increased from $60 \%$ to $70 \%$, and the compressive strength retention rate decreased slowly. When the theoretical $\mathrm{MgO}$ content exceeded $70 \%$, the compression strength retention rate gradually increased; that is, the water resistance of the SAC-MKPC paste decreased with an increase in the theoretical MgO content. When the M/P was 3, the compressive retention rate of the SAC-MKPC showed a significant decrease with an increase in the theoretical $\mathrm{MgO}$ content. Hence, the water resistance of the SAC-MKPC worsened with an increase in the $\mathrm{MgO}$ content when the $\mathrm{M} / \mathrm{P}$ was constant. When the theoretical $\mathrm{MgO}$ content was $60-70 \%$, the water resistance of the SAC-MKPC improved.

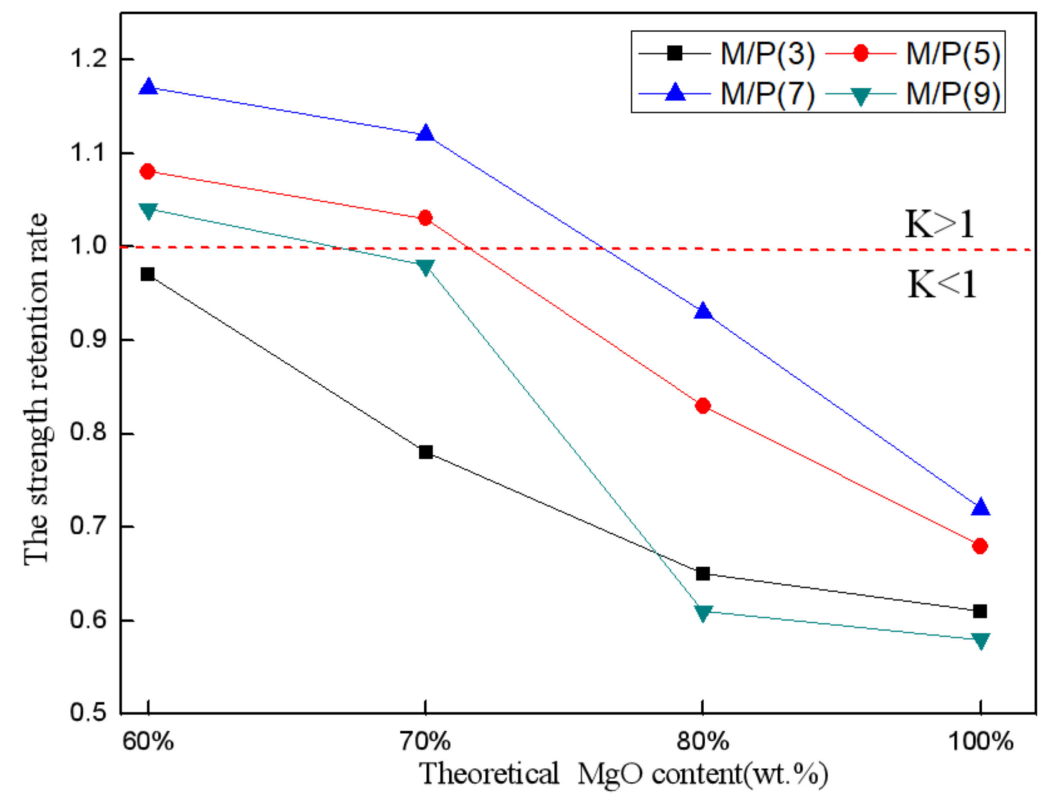

Figure 13. Water resistance of the SAC-MKPC.

Figure 13 also shows that the compressive strength retention rate of the SAC-MKPC decreased with an increase in the $\mathrm{M} / \mathrm{P}$ when the theoretical $\mathrm{MgO}$ content was constant. 
When the theoretical $\mathrm{MgO}$ content remained unchanged, the water resistance of the SACMKPC increased first and then decreased with the increase in the M/P. When the M/P was 7 , the compressive strength retention rate was the largest; that is, the SAC-MKPC had the highest water resistance. According to the above result, when the M/P was 5, the theoretical $\mathrm{MgO}$ contents were $60 \%$ and $70 \%$; when the $\mathrm{M} / \mathrm{P}$ was 7 , the theoretical $\mathrm{MgO}$ content was $60 \%$ and $70 \%$; and when the $\mathrm{M} / \mathrm{P}$ was 9 , the theoretical $\mathrm{MgO}$ content was $60 \%$. For a compressive strength retention rate $\mathrm{K}$ greater than 1 , the test blocks that were prepared by SAC-MKPC did not experience a decrease in strength during water curing, and the compressive strength increased slightly. The main reasons for the strength decrease and the reverse enhancement in the SAC-MKPC test block cured in a water environment were that the $\mathrm{M} / \mathrm{P}$ was too high, the proportion of sulfoaluminate in the SAC-MKPC system was high, no unreacted $\mathrm{KH}_{2} \mathrm{PO}_{4}$ existed in the hydration product, the SAC-MKPC block did not form pores that were dissolved by $\mathrm{KH}_{2} \mathrm{PO}_{4}$ during water curing, the dense structure was not destroyed, and the strength did not decrease. Although the hydration product $\mathrm{MgKPO}_{4} \cdot 6 \mathrm{H}_{2} \mathrm{O}$ was dissolved partially in the acidic water environment, micropores formed by the dissolution of the unreacted calcium sulfoaluminate could be hydrated to generate ettringite, and they filled the micropores. The compactness of the inner structure improved, and the compressive strength retention rate increased [38-41]. The SAC-MKPC system exhibited better mechanical properties. Hence, the SAC-MKPC cementitious composite material was prepared at a low calcination temperature.

\subsection{Reaction Pathways of Mineral Formation}

Based on the performance analysis of the SAC-MKPC prepared from industrial solid wastes, the main formation mechanism of SAC-MKPC can be proposed.

The mineral phase of carbide slag decomposed into calcium oxide, water, and carbon dioxide.

$$
\begin{aligned}
\mathrm{Ca}(\mathrm{OH})_{2} & \rightarrow \mathrm{CaO}+\mathrm{H}_{2} \mathrm{O} \\
\mathrm{CaCO}_{3} & \rightarrow \mathrm{CaO}+\mathrm{CO}_{2}
\end{aligned}
$$

Magnesium sulfite hexahydrate of the magnesium desulfurization slag decomposed into magnesium oxide, sulfur dioxide, and oxygen.

$$
\begin{gathered}
\mathrm{MgSO}_{3} \rightarrow \mathrm{MgO}+\mathrm{SO}_{2} \\
2 \mathrm{MgSO}_{4} \rightarrow 2 \mathrm{MgO}+2 \mathrm{SO}_{2}+\mathrm{O}_{2}
\end{gathered}
$$

A more stable calcium sulfate phase formed from sulfur dioxide, oxygen, and calcium oxide.

$$
2 \mathrm{CaO}+2 \mathrm{SO}_{2}+\mathrm{O}_{2} \rightarrow 2 \mathrm{CaSO}_{4}
$$

Calcium oxide, aluminium oxide, and calcium sulfate transformed into the ye'elimite phase. Magnesium oxide became dead-burnt magnesium oxide.

$$
\begin{gathered}
3 \mathrm{CaO}+3 \mathrm{Al}_{2} \mathrm{O}_{3}+\mathrm{CaSO}_{4} \rightarrow 3 \mathrm{CaO} \cdot 3 \mathrm{Al}_{2} \mathrm{O}_{3} \cdot \mathrm{CaSO}_{4} \\
\mathrm{MgO} \rightarrow \text { dead-burnt } \mathrm{MgO}
\end{gathered}
$$

MKPC was generated based on an acid-neutralization reaction. Equation (17) shows that the MKPC generation process is a high-speed reaction compared with SAC hydration. Therefore, MKPC was an early stage reaction product, which is critical to the early stage compressive strength.

$$
\begin{gathered}
\mathrm{MgO}+\mathrm{KH}_{2} \mathrm{PO}_{4}+5 \mathrm{H}_{2} \mathrm{O} \rightarrow \mathrm{MgKPO}_{4} \cdot 6 \mathrm{H}_{2} \mathrm{O} \\
3 \mathrm{CaO} \cdot 3 \mathrm{Al}_{2} \mathrm{O}_{3} \cdot \mathrm{CaSO}_{4}+2\left(\mathrm{CaSO}_{4} \cdot 2 \mathrm{H}_{2} \mathrm{O}\right)+34 \mathrm{H}_{2} \mathrm{O} \rightarrow \\
3 \mathrm{CaO} \cdot \mathrm{Al}_{2} \mathrm{O}_{3} \cdot 3 \mathrm{CaSO}_{4} \cdot 32 \mathrm{H}_{2} \mathrm{O}+2\left(\mathrm{Al}_{2} \mathrm{O}_{3} \cdot 3 \mathrm{H}_{2} \mathrm{O}\right)(\mathrm{gel})
\end{gathered}
$$


In the SAC-MKPC system, the K-struvite crystal formed first and the AFt formed later. The K-struvite crystal changed gradually into a large bulk phase and the K-struvite surface was covered with AFt crystals. The two main mineral phases, k-struvite and AFt, were linked, and therefore they formed a dense structure [42-44].

\section{Conclusions}

We conducted experimental research on the SAC-MKPC cementitious composite material that was produced from aluminum slag, carbide slag, coal gangue, and magnesium desulfurization slag, with a focus on the theoretical feasibility of preparing SAC-MKPC clinker from industrial solid wastes and the main formation mechanism. The mechanical strength of the hydration product, the phases in the clinker, and the thermogravimetry, microstructure, and water resistance of the SAC-MKPC paste were researched in detail. According to the experimental results, our conclusions are as follows:

(1) The expected main mineral phases $\left(\mathrm{MgO}\right.$, ye'elimite, and $\left.\mathrm{Ca}_{2} \mathrm{SiO}_{4}\right)$ formed in the SAC-MKPC clinker, and the calcination temperature of the main mineral phases formed was between $1250{ }^{\circ} \mathrm{C}$ and $1350{ }^{\circ} \mathrm{C}$.

(2) The SAC-MKPC had better strength behavior when the calcination temperature was $\sim 1300{ }^{\circ} \mathrm{C}$, the theoretical $\mathrm{MgO}$ content was $60-70 \%$, and the $\mathrm{M} / \mathrm{P}$ was 5 and 7 . The best compressive strength reached 35.2, 70.9, 84.1, 87.7, and 101.6 MPa at $2 \mathrm{~h}, 1 \mathrm{~d}, 3 \mathrm{~d}$, $7 \mathrm{~d}$, and $28 \mathrm{~d}$ of hydration, respectively.

(3) The XRD analysis of the hydration products of the SAC-MKPC composite indicated that K-struvite and ettringite coexisted. The SEM micrographs also showed that the mutual adhesion of the FAt and K-struvite crystals led to the formation of a very dense structure. The dense structure provided the SAC-MKPC with excellent water resistance. This novel preparation method could use industrial solid wastes as raw materials to prepare SAC-MKPC cementitious composite materials of high value.

Author Contributions: C.R.: Writing-original draft. W.W.: Formal analysis. D.H.: Methodology. S.W.: Conceptualization and Data curation. Y.Y.: Writing-review and editing. All authors have read and agreed to the published version of the manuscript.

Funding: This research was funded by the National Key Research \& Development Program of China, grant number 2017YFC0703100, the Qilu University of Technology (Shandong Academy of Sciences) Young Doctors Cooperative Fund, grant number 2019BSHZ0017, and the Qilu University of Technology (Shandong Academy of Sciences) Pilot Project for the Integrate Production and Education Fund, grant number 2020KJC-ZD12.

Data Availability Statement: The data presented in this study are available on request from the corresponding author.

Conflicts of Interest: The authors declare that they have no known competing financial interests or personal relationships that could have appeared to influence the work reported in this paper.

\section{References}

1. Arunabh, M.; Kamalesh, K.S. Recovery of valuable products from hazardous aluminum dross: A review. Resour. Conserv. Recy. 2018, 130, 95-108.

2. Nai, C.X.; Tang, M.Q.; Liu, Y.Q.; Xu, Y. Potentially contamination and health risk to shallow groundwater caused by closed industrial solid waste landfills: Site reclamation evaluation strategies. J. Clean. Prod. 2021, 286, 125402. [CrossRef]

3. Hosein, N.; Masoomeh, M. Estimating the compressive strength of eco-friendly concrete incorporating recycled coarse aggregate using neuro-fuzzy approach. J. Clean. Prod. 2020, 265, 121886.

4. Weng, Y.W.; Ruan, S.Q.; Li, M.Y.; Mo, L.W. Feasibility study on sustainable magnesium potassium phosphate cement paste for 3D printing. Constr. Build. Mater. 2019, 221, 595-603. [CrossRef]

5. Li, J.; Zhang, W.; Cao, Y. Laboratory evaluation of magnesium phosphate cement paste and mortar for rapid repair of cement concrete pavement. Constr. Build. Mater. 2014, 58, 122-128. [CrossRef]

6. Li, J.; Zhang, W.; Monteiro, P.J. Mechanical properties of struvite-K: A high-pressure X-ray diffraction study. Cem. Concr. Res. 2020, 136, 106171. [CrossRef]

7. Xu, B.W.; Ma, H.Y.; Shao, H.Y.; Li, Z.J. Influence of fly ash on compressive strength and micro-characteristics of magnesium potassium phosphate cement mortars. Cem. Concr. Res. 2017, 99, 86-94. [CrossRef] 
8. Zheng, D.D.; Wang, C.Q.; Sun, C.J.; Lin, X.J. Effect of the combination of fly ash and silica fume on water resistance of MagnesiumPotassium Phosphate Cement. Constr. Build. Mater. 2016, 106, 415-421. [CrossRef]

9. Wang, Q.; Yu, C.J.; Yang, J.M.; Chong, L.L. Influence of nickel slag powders on properties of magnesium potassium phosphate cement paste. Constr. Build. Mater. 2019, 205, 668-678. [CrossRef]

10. Lu, X.; Chen, B. Experimental study of magnesium phosphate cements modified by metakaolin. Constr. Build. Mater. 2016, 123, 719-726. [CrossRef]

11. Tan, Y.S.; Yu, H.F.; Li, Y.; Bi, W.L. The effect of slag on the properties of magnesium potassium phosphate cement. Constr. Build. Mater. 2016, 126, 313-320. [CrossRef]

12. Li, G.X.; Zhang, J.J.; Zhang, G. Mechanical property and water stability of the novel SAC-MKPC blended system. Constr. Build. Mater. 2017, 136, 99-107. [CrossRef]

13. Zhang, T.; Chen, H.S.; Li, X.Y.; Zhu, Z.G. Hydration behavior of magnesium potassium phosphate cement and stability analysis of its hydration products through thermodynamic modeling. Cem. Concr. Res. 2017, 98, 101-110. [CrossRef]

14. Qiao, F. Reaction Mechanisms of Magnesium Potassium Phosphate Cement and its Application. PhD Thesis, Hong Kong University of Science and Technology, Hong Kong, China, 2010.

15. Ren, C.Z.; Wang, W.L.; Wu, S.; Yao, Y.G. Preparation of sulphoaluminate-magnesium potassium phosphate cementitious composite material under low-temperature. Constr. Build. Mater. 2019, 202, 246-253. [CrossRef]

16. National Standard of the People's Republic of China. Test Methods for Water Requirement of Normal Consistency, Setting Time and Soundness of the Portland Cement; P GBT1346-2011; The Standardization Administration of China: Beijing, China.

17. Wu, S.; Yao, X.L.; Ren, C.Z.; Yao, Y.G. Recycling phosphor-gypsum as a sole calcium oxide source in calcium sulfoaluminate cement and its environmental effects. J. Environ. Manag. 2020, 271, 110986. [CrossRef]

18. Li, W.T.; Yi, Y.L. Use of carbide slag from acetylene industry for activation of ground granulated blast-furnace slag. Constr. Build. Mater. 2020, 238, 611-713. [CrossRef]

19. Kou, R.; Guo, M.Z.; Han, L.; Li, J.S.; Li, B.; Chu, H.Q. Recycling sediment, calcium carbide slag and ground granulated blastfurnace slag into novel and sustainable cementitious binder for production of eco-friendly mortar. Constr. Build. Mater. 2021, 305, 124772. [CrossRef]

20. Benjamin, D.; Galloway, E.S.; Bihter, P. Binding of $\mathrm{SO}_{3}$ to fly ash components: $\mathrm{CaO}, \mathrm{MgO}, \mathrm{Na}_{2} \mathrm{O}$ and $\mathrm{K}_{2} \mathrm{O}$. Fuel 2015, 145 , 79-83.

21. Aphan, M.E.; Merwe, V.D.; Strydom, C.A. The effect of calcining conditions on the rehydration of dead burnt magnesium oxide using magnesium acetate as a hydrating agent. J. Therm. Anal. Calorim. 2005, 80, 659-662.

22. Li, Y.; Sun, J.; Chen, B. Experimental study of magnesia and M/P ratio influencing properties of magnesium phosphate cement Constr. Build. Mater. 2014, 65, 177-183. [CrossRef]

23. Xu, B.; Ma, H.; Li, Z. Influence of magnesia-to-phosphate molar ratio on microstructures, mechanical properties and thermal conductivity of magnesium potassium phosphate cement paste with large water-to-solid ratio. Cem. Concr. Res. 2015, 68, 1-9. [CrossRef]

24. Ma, H.; Xu, B.; Liu, J.; Pei, H.; Li, Z. Effects of water content, magnesia-to-phosphate molar ratio and age on pore structure, strength and permeability of magnesium potassium phosphate cement paste. Mater. Des. 2014, 64, 497-502. [CrossRef]

25. Qiao, F.; Chau, C.K.; Li, Z. Property evaluation of magnesium phosphate cement mortar as patch repair material. Constr. Build. Mater. 2010, 24, 695-700. [CrossRef]

26. Li, Y.; Chen, B. Factors that affect the properties of magnesium phosphate cement. Constr. Build. Mater. 2013, 47, 977-983. [CrossRef]

27. Tan, H.B.; Li, M.G.; He, X.Y.; Su, Y. Effect of wet grinded lithium slag on compressive strength and hydration of sulphoaluminate cement system. Constr. Build. Mater. 2020, 10, 465-472. [CrossRef]

28. Tang, H.; Qian, J.S.; Ji, Z.W.; Dai, X.B.; Li, Z. The protective effect of magnesium phosphate cement on steel corrosion. Constr. Build. Mater. 2020, 255, 422-431. [CrossRef]

29. National Standard of the People's Republic of China. Code for Acceptance of Constructional Quality of Concrete Structures; P GB 50204-2002; The Standardization Administration of China: Beijing, China.

30. Rouzic, M.L.; Chaussadent, T.; Stefan, L.; Saollio, M. On the influence of Mg/P ratio on the properties and durability of magnesium potassium phosphate cement pastes. Cem. Concr. Res. 2017, 96, 27-41. [CrossRef]

31. Pera, J.; Ambroise, J. New applications of calcium sulfoaluminate cement. Cem. Concr. Res. 2004, 34, 671-676. [CrossRef]

32. Zhang, G.; Li, G.X.; He, T.S. Effects of sulphoaluminate cement on the strength and water stability of magnesium potassium phosphate cement. Constr. Build. Mater. 2017, 132, 335-342. [CrossRef]

33. Liu, Y.; Fu, H.F.; Zhang, H.; Sun, F.L. Microstructure, hardness, and shear behavior of the as-soldered SnBi-SAC composite solder pastes. J. Mater. Sci. 2017, 28, 113-120. [CrossRef]

34. Chau, C.K.; Qiao, F.; Li, Z.J. Microstructure of magnesium potassium phosphate cement. Constr. Build. Mater. 2011, $25,2911-2917$. [CrossRef]

35. Ma, H.; Xu, B.W.; Li, Z.J. Magnesium potassium phosphate cement paste: Degree of reaction, porosity and pore structure. Cem. Concr. Res. 2014, 65, 96-104. [CrossRef]

36. Li, D.X.; Li, P.X.; Feng, C.H. Research on water resistance of magnesium phosphate cement. J. Build. Mater. 2009, 12, 505-510.

37. Mao, M.; Wang, Z.; Jia, X.W. Researching on water resistance improvement of magnesium phosphate cement. Non-Met. Mines 2019, 35, 1-3. 
38. Chong, L.L.; Yang, J.M.; Shi, C.J. Effect of curing regime on water resistance of magnesium-potassium phosphate cement. Constr. Build. Mater. 2017, 151, 43-51. [CrossRef]

39. Ding, Z.; Dong, B.; Xing, F.; Han, N.; Li, Z. Cementing mechanism of potassium phosphate based magnesium phosphate cement. Ceram. Int. 2012, 38, 6281-6288. [CrossRef]

40. Liao, W.Y.; Ma, H.Y.; Sun, H.F.; Huang, Y.; Wang, Y.C. Potential large-volume beneficial use of low-grade fly ash in magnesiaphosphate cement based materials. Fuel 2017, 209, 490-497. [CrossRef]

41. Liu, N.; Chen, B. Experimental research on magnesium phosphate cements containing alumina. Constr. Build. Mater. 2016, 121, 354-360. [CrossRef]

42. Glasser, F.P.; Zhang, L. High-performance cement matrices based on calcium sulfoaluminate-belite compositions. Cem. Concr. Res. 2001, 31, 1881-1886. [CrossRef]

43. Li, Y.; Li, J.; Guo, H. Preparation and study of light transmitting properties of sulfoaluminate cement-based materials. Mater. Des. 2015, 83, 185-192. [CrossRef]

44. Li, G.X.; Zhang, J.J.; Song, Z.P.; Shi, C.; Zhang, A. Improvement of workability and early strength of calcium sulphoaluminate cement at various temperature by chemical admixtures. Constr. Build. Mater. 2018, 60, 427-439. [CrossRef] 